\title{
Technical Note-Relative Variability of Selected Turbidity Standards and Sensors in Use by the U.S. Geological Survey
}

Open-File Report 2021-1009 



\section{Technical Note-Relative Variability of Selected Turbidity Standards and Sensors in Use by the U.S. Geological Survey}

By Guy M. Foster, Lindsey R. King, John D. Jastram, John K. Joiner, Brian A.

Pellerin, Jennifer L. Graham, and Thomas J. Williams

Open-File Report 2021-1009 


\section{U.S. Geological Survey, Reston, Virginia: 2021}

For more information on the USGS - the Federal source for science about the Earth, its natural and living resources, natural hazards, and the environment—visit https://www.usgs.gov or call 1-888-ASK-USGS.

For an overview of USGS information products, including maps, imagery, and publications, visit https://store.usgs.gov/.

Any use of trade, firm, or product names is for descriptive purposes only and does not imply endorsement by the U.S. Government.

Although this information product, for the most part, is in the public domain, it also may contain copyrighted materials as noted in the text. Permission to reproduce copyrighted items must be secured from the copyright owner.

Suggested citation:

Foster, G.M., King, L.R., Jastram, J.D., Joiner, J.K., Pellerin, B.A., Graham, J.L., and Williams, T.J., 2021, Technical note-Relative variability of selected turbidity standards and sensors in use by the U.S. Geological Survey: U.S. Geological Survey Open-File Report 2021-1009, 41 p., 23 app., https://doi.org/10.3133/ofr20211009.

Associated data for this publication:

King, L.R., 2021, Laboratory and field data for selected turbidity standard and sensor comparisons, October 2014 to September 2017: U.S. Geological Survey data release, https://doi.org/10.5066/P9EVSDHH.

ISSN 2331-1258 (online) 


\section{Contents}

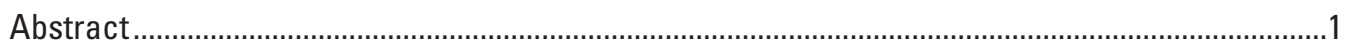

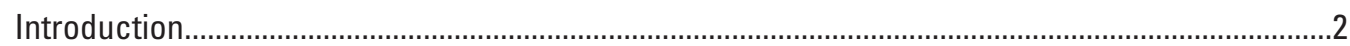

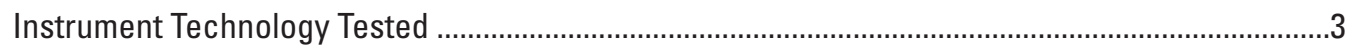

Standards Used for Turbidity-Sensor Calibrations...................................................................

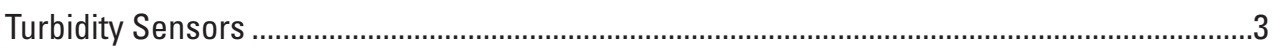

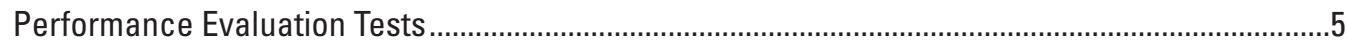

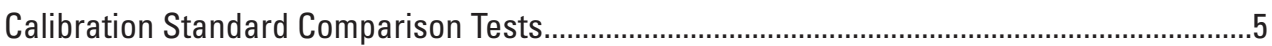

Sensor Comparison Tests....................................................................................................

Testing Materials ......................................................................................................................6

Quality-Assurance Calibration Checks of Turbidity Sensors and Quality Assurance

of Calibration Standards ............................................................................................

Laboratory Tests..................................................................................................................

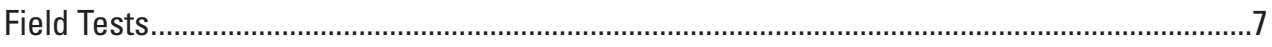

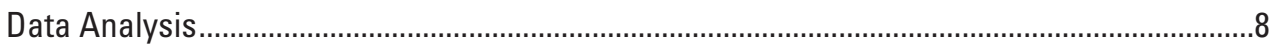

Results of Calibration Standard Comparison Tests ...................................................................12

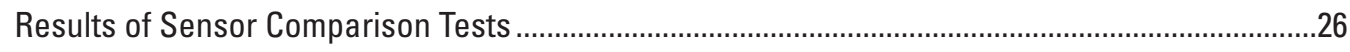

Relative Variability of Selected Turbidity Standards and Sensors ..................................................35

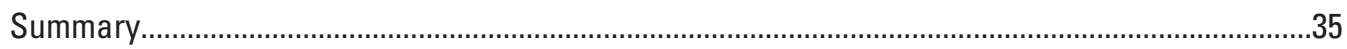

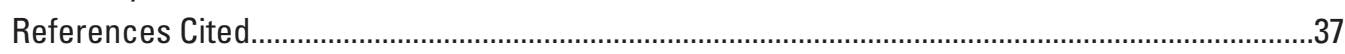

Appendix 1. Field Comparison Between StablCal and Polymer Turbidity Standards at Neosho River at Burlingame Road Near Emporia, Kansas (U.S. Geological Survey Station Number 07179750), May 16 to June 27, 2017.

Appendix 2. Field Comparison Between StablCal and Polymer Turbidity Standards at Kansas River at De Soto, Kansas (U.S. Geological Survey Station Number 06892350), May 16 to June 24, 2017.

Appendix 3. Laboratory Comparison Between StablCal and Polymer Turbidity Standards Using White Clay at the Kansas Water Science Center Laboratory, Lawrence, Kansas.

Appendix 4. Laboratory Comparison Between StablCal and Polymer Turbidity Standards Using Pink Clay at the Kansas Water Science Center Laboratory, Lawrence, Kansas...

Appendix 5. Laboratory Comparison Between StablCal and Polymer Turbidity Standards Using Natural Sediment and Water (From the Neosho River at Neosho Rapids, Kansas, U.S. Geological Survey [USGS] Station Number 07182390) at the Kansas Water Science Center Laboratory, Lawrence, Kansas .

Appendix 6. Laboratory Comparison Between StablCal and Multiple Lots of Polymer Turbidity Standard at the Kansas Water Science Center Laboratory, Lawrence, Kansas.

Appendix 7. Laboratory Comparison Between StablCal and Multiple Lots of Polymer Turbidity Standard Using Natural Sediment and Water (From the Neosho River at Neosho Rapids, Kansas, U.S. Geological Survey [USGS] Station Number 07182390) at the Kansas Water Science Center Laboratory, Lawrence, Kansas on September 7, 2017.

Appendix 8. Laboratory Comparison Between StablCal and Multiple Lots of Polymer Turbidity Standard Using White Clay at the Kansas Water Science Center Laboratory, Lawrence, Kansas 
Appendix 9. Laboratory Comparison Between StablCal and Multiple Lots of Polymer Turbidity Standard Using Natural Sediment and Water (From the Neosho River at Neosho Rapids, Kansas, U.S. Geological Survey Station Number 07182390) at the Kansas Water Science Center Laboratory, Lawrence, Kansas on September 15, 2017 ...

Appendix 10. Field Comparison Between YSI EXO and YSI 6136 Turbidity Sensors at Little Arkansas River at Highway 50 Near Halstead, Kansas (U.S. Geological Survey [USGS] Station Number 07143672), January 25 to June 28, 2017.

Appendix 11. Field Comparison Between YSI EXO and YSI 6136 Turbidity Sensors at Little Arkansas River Near Sedgwick, Kansas (U.S. Geological Survey [USGS] Station Number 07144100), March 30 to June 28, 2017.

Appendix 12. Field Comparison Between YSI EXO and YSI 6136 Turbidity Sensors at North Fork Ninnescah River Above Cheney Reservoir, Kansas (U.S. Geological Survey [USGS] Station Number 07144780), March 31 to June 7, 2017

Appendix 13. Field Comparison Between YSI EXO and YSI 6136 Turbidity Sensors at Cheney Reservoir Near Cheney, Kansas (U.S. Geological Survey [USGS] Station Number 07144790), October 1, 2014 to March 12, 2015.

Appendix 14. Field Comparison Between YSI EXO and YSI 6136 Turbidity Sensors at Neosho River at Neosho Rapids, Kansas (U.S. Geological Survey [USGS] Station Number 07182390), April 4 to May 9, 2017 ...

Appendix 15. Field Comparison Between YSI EX0 and YSI 6136 Turbidity Sensors at Neosho River at Burlington, Kansas (U.S. Geological Survey [USGS] Station Number 07182510), May 9 to May 16, 2017...

Appendix 16. Field Comparison Between YSI EXO and YSI 6136 Turbidity Sensors at Mill Creek at Johnson Drive, Shawnee, Kansas (U.S. Geological Survey [USGS] Station Number 06892513), August 16 to August 31, 2017

Appendix 17. Field Comparison Between YSI EXO and YSI 6136 Turbidity Sensors at James River at Cartersville, Virginia (U.S. Geological Survey [USGS] Station Number 02035000), October 7, 2016 to July 10, 2017.

Appendix 18. Field Comparison Between YSI EXO and YSI 6136 Turbidity Sensors at Difficult Run Above Fox Lake Near Fairfax, Virginia (U.S. Geological Survey [USGS] Station Number 01645704), May 6 to July 25, 2017

Appendix 19. Laboratory Comparison Between YSI EXO and YSI 6136 Turbidity Sensors Using White Clay at the Kansas Water Science Center Laboratory, Lawrence, Kansas.

Appendix 20. Laboratory Comparison Between YSI EXO and YSI 6136 Turbidity Sensors Using Black Clay at the Kansas Water Science Center Lab, Lawrence, Kansas..

Appendix 21. Laboratory Comparison Between YSI EXO and YSI 6136 Turbidity Sensors Using Pink Clay at the Kansas Water Science Center Laboratory, Lawrence, Kansas .....41

Appendix 22. Laboratory Comparison Between YSI EXO and YSI 6136 Turbidity Sensors Using Natural Sediment and Water (From Mill Creek at Johnson Drive, Shawnee, Kansas, U.S. Geological Survey [USGS] station number 06892513) at the Kansas Water Science Center Lab, Lawrence, Kansas

Appendix 23. Laboratory Comparison Between YSI EXO and YSI 6136 Turbidity Sensors Using Natural Sediment and Water (From the Kansas River at Wamego, Kansas, U.S. Geological Survey [USGS] Station Number 06887500) at the Kansas Water Science Center Lab, Lawrence, Kansas 


\section{Figures}

1. Yellow Springs Instruments (YSI) 6136 turbidity sensor ......................................................

2. Yellow Springs Instruments (YSI) EXO turbidity sensor .......................................................

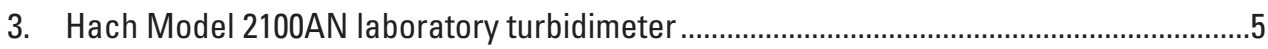

4. Laboratory turbidity testing apparatus and benchtop turbidimeter.................................8

5. Generalized lid configuration for laboratory testing apparatus .......................................9

6. Graph showing generalized pattern of results of laboratory turbidity tests using Yellow Springs Instruments EXO and 6136 turbidity sensors and the $\mathrm{HACH}$ 2100AN turbidimeter.

7. Maps showing turbidity sensor and turbidity calibration standard comparison sites.

8. Graphs showing linear association for all field comparisons of StablCal and polymer turbidity standards, relative percentage difference (RPD) for all field comparisons for StablCal and polymer turbidity standards, and difference in turbidity for all field comparisons for StablCal and polymer turbidity standards

9. Graphs showing difference in measurements of turbidity in white clay and deionized-water solutions between Yellow Springs Instruments EXO turbidity sensors calibrated with StabICal and polymer turbidity standards in relation to Hach 2100AN turbidimeter; and difference in measurements of native water and sediment solutions between Yellow Springs Instruments EXO turbidity sensors calibrated with StabICal and polymer turbidity standards in relation to the Hach 2100AN turbidimeter.

10. Graphs showing difference between measurements made with Yellow Springs Instruments EXO turbidity sensors calibrated with two different lot numbers of polymer turbidity standards in relation to Hach 2100AN turbidimeter, for comparisons with a white clay and deionized-water solution and a solution of sediment and water.

11. Graphs showing linear association for all field comparisons of Yellow Springs Instruments (YSI) EXO and YSI 6136 turbidity sensors, relative percentage difference for all field comparisons for YSI EXO and YSI 6136 turbidity sensors, and difference in turbidity for all field comparisons for YSI EXO and YSI 6136 turbidity sensors

12. Graphs showing difference between Yellow Springs Instruments (YSI) 6136 and YSI EXO turbidity measurements in relation to the Hach 2100AN turbidimeter for measurements made in white clay and deionized-water solution, pink clay and deionized-water solution, and black clay and deionized-water solution.

13. Graph showing difference between Yellow Springs Instruments (YSI) 6136 and YSI EXO turbidity measurements in relation to the Hach 2100AN turbidimeter for measurements made in a solution of sediment and water.

\section{Tables}

1. Summary of the laboratory and field comparisons and associated appendixes that contain comparison descriptions and results 3

2. Standard verification measurements made with the Hach 2100AN turbidimeter .............7

3. Site locations for field turbidity sensor comparison tests ...............................................12

4. Site locations for field turbidity standard comparison tests ............................................12 
5. Summary of StabICal and polymer-calibrated Yellow Springs Instruments (YSI) EXO turbidity sensor field comparisons

6. Summary of StabICal- and polymer-calibrated Yellow Springs Instruments (YSI) EXO turbidity sensor laboratory comparisons

7. Summary of laboratory comparisons of individual turbidity sensors calibrated by using different lots of polymer standard.

8. Summary of comparisons between the Hach 2100AN turbidimeter and Yellow Springs Instruments EXO turbidity sensors calibrated by using different lots of StableCal standard

9. Summary of comparisons between the Hach 2100AN turbidimeter and Yellow Springs Instruments EXO turbidity sensors calibrated by using different lots of polymer standard

10. Summary of Yellow Springs Instruments (YSI) EXO and YSI 6136 sensor field comparisons.

11. Summary of Yellow Springs Instruments (YSI) EXO turbidity sensor, YSI 6136 turbidity sensor, and Hach 2100AN turbidimeter laboratory comparisons

\section{Conversion Factors}

U.S. customary units to International System of Units

\begin{tabular}{|c|c|c|}
\hline Multiply & By & To obtain \\
\hline \multicolumn{3}{|c|}{ Length } \\
\hline inch (in.) & 2.54 & centimeter $(\mathrm{cm})$ \\
\hline inch (in.) & 25.4 & millimeter $(\mathrm{mm})$ \\
\hline \multicolumn{3}{|c|}{ Volume } \\
\hline gallon (gal) & 3.785 & liter (L) \\
\hline gallon (gal) & 0.003785 & cubic meter $\left(\mathrm{m}^{3}\right)$ \\
\hline gallon (gal) & 3.785 & cubic decimeter $\left(\mathrm{dm}^{3}\right)$ \\
\hline
\end{tabular}

Temperature in degrees Celsius $\left({ }^{\circ} \mathrm{C}\right)$ may be converted to degrees Fahrenheit $\left({ }^{\circ} \mathrm{F}\right)$ as follows:

$$
{ }^{\circ} \mathrm{F}=\left(1.8 \times{ }^{\circ} \mathrm{C}\right)+32 .
$$

Temperature in degrees Fahrenheit $\left({ }^{\circ} \mathrm{F}\right)$ may be converted to degrees Celsius $\left({ }^{\circ} \mathrm{C}\right)$ as follows:

$$
{ }^{\circ} \mathrm{C}=\left({ }^{\circ} \mathrm{F}-32\right) / 1.8 .
$$

\section{Supplemental Information}

Specific conductance is given in microsiemens per centimeter at 25 degrees Celsius $\left(\mu \mathrm{S} / \mathrm{cm}\right.$ at $\left.25^{\circ} \mathrm{C}\right)$. 


\section{Abbreviations}

$\begin{array}{ll}\text { EPA } & \text { U.S. Environmental Protection Agency } \\ \text { FNU } & \text { formazin nephelometric units } \\ \text { ISO } & \text { International Organization for Standardization } \\ \text { LED } & \text { light-emitting diode } \\ \text { nm } & \text { nanometer } \\ \text { NTRU } & \text { nephelometric turbidity ratio units } \\ \text { NTU } & \text { nephelometric turbidity units } \\ \text { NWIS } & \text { National Water Information System } \\ \text { NWOL } & \text { National Water Quality Laboratory } \\ \text { USGS } & \text { U.S. Geological Survey }\end{array}$





\title{
Technical Note—Relative Variability of Selected Turbidity Standards and Sensors in Use by the U.S. Geological Survey
}

\author{
By Guy M. Foster, Lindsey R. King, John D. Jastram, John K. Joiner, Brian A. Pellerin, Jennifer L. Graham, and \\ Thomas J. Williams
}

\section{Abstract}

The challenges associated with field measurements of turbidity are well known and result primarily from differences in reported values that depend on instrument design and the resulting need for reporting units that are specific to those designs. A critical challenge for making comparable turbidity measurements is the selection and use of appropriate turbidity standards for sensor calibration. The accepted primary standards for turbidity measurements use formazin made from scratch; all others should relate back to readings obtained using standard formazin. However, because turbidity is a qualitative property of water, comparing standards is not as simple as it is for many chemical measurements. The U.S. Geological Survey "National Field Manual for the Collection of WaterQuality Data" currently allows for the use of two standards, formazin and polymer beads, for the calibration of field turbidimeters. Another challenge for making comparable turbidity measurements is selection of turbidity sensors. A turbidity sensor commonly used in the U.S. Geological Survey, the Yellow Springs Instruments (YSI) 6136, has been replaced by the manufacturer with the YSI EXO turbidity sensor. Both sensors operate on the same principles but have slight design differences that result in readings that are not directly comparable on a 1:1 basis.

Differences in calibration standards and sensors are a cause of concern in ongoing studies that require switching calibration standards or sensor types, and for comparisons of data collected with sensors calibrated by using different calibration standards, different sensor types, or both. The objectives of this study were to evaluate the response of two YSI turbidity sensors in both formazin-based standards (StablCal) and polymer turbidity standards (in this case YSI brand; however, other brands are available) and to compare the performance of the YSI EXO and YSI 6136 turbidity sensors under similar laboratory and environmental (field) conditions. To quantify these differences, a series of laboratory and field side-by-side comparisons were conducted. Nine field comparisons of YSI EXO and YSI 6136 sensors were performed at site locations in Kansas and Virginia. Two field comparisons of StablCal and polymer calibration standards were performed in Kansas, both using YSI EXO turbidity sensors. Five laboratory comparisons between the YSI EXO and YSI 6136 turbidity sensors were performed, and seven laboratory comparisons between StablCal and polymer turbidity standards were performed using YSI EXO turbidity sensors. The results can help the USGS and others better understand how turbidity data can differ depending on the sensors and calibration standards used.

Key findings and conclusions include the following-

- Regardless of the comparison, strong linear associations were typically found across all measures of turbidity under field and laboratory conditions, but linear associations were not necessarily 1:1 and varied by type of standard, type of sensor, and field and laboratory conditions.

- The mean relative percentage differences for all but a few comparisons were greater than 10 percent but less than 30 percent. However, differences were inconsistent across the laboratory and field conditions measured in this study, precluding the ability to formulate definitive statements of consistent directional bias depending on the type of standard or sensor used.

- Across all tests and a range of 0 to 1,000 formazin nephelometric units (FNU), no consistent bias between the YSI EXO and YSI 6136 turbidity sensors was observed, but either regression relations were near 1:1 or the YSI EXO turbidity readings were lower than those measured with the YSI 6136. Relative percentage differences typically exceeded the 10- and 30-percent benchmarks. However, most (about 95 percent) of the absolute differences between turbidity values measured with the YSI EXO and those measured with the YSI 6136 sensors were less than $20 \mathrm{FNU}$.

- In laboratory experiments, when turbidity was "constant," the absolute difference between YSI EXO and YSI 6136-measured turbidity values ranged from near $0 \mathrm{FNU}$ to nearly $400 \mathrm{FNU}$ (over a range of 0 to 
1,000 FNU). Substantial variability in turbidity measurements makes comparison between standards and sensor types challenging.

- Given the inherent variability in turbidity measurements and the lack of consistent bias between calibration standards or sensors, changing methods during an ongoing study would compromise the comparability of the data. The effect of changing methods ultimately depends on study objectives. If method changes are required, laboratory- and field-based comparisons across a range of conditions ideally would be conducted to determine whether site-specific biases can be identified.

\section{Introduction}

Turbidity is a qualitative measure of the optical clarity of water and is an indicator of the environmental health of water bodies. A detailed discussion of turbidity and how it is used to assess environmental waters can be found in Anderson (2005). Many challenges associated with making comparable field turbidity measurements are well known (Anderson, 2005; Sadar, 2003). These issues result primarily from differences in reported values that depend on instrument design (Anderson, 2005). However, another critical consideration for making comparable turbidity measurements is the selection and use of appropriate standards for sensor calibration. Differences in calibration standards and sensors cause concern for ongoing studies if they require switching calibration standards or sensor types, and for comparisons of data collected with sensors calibrated by using different calibration standards, different sensor types, or both.

The U.S. Geological Survey (USGS) National Field Manual for the Collection of Water-Quality Data (U.S. Geological Survey, variously dated) currently allows for the use of two standards, formazin and polymer beads (hereafter called "polymer"), for the calibration of field turbidimeters (Anderson, 2005; Wagner and others, 2006). Formazin is commonly used as a primary standard for turbidity-sensor calibration because it can be consistently reproduced from assayed raw material and its physical characteristics make it a desirable light-scatter calibration standard. The calibration process provides a common basis for standardization, and if turbidity were an inherent physical property, then measurements of environmental waters would be expected to have similar numerical values for any instrument. However, the varying particle and color characteristics of environmental waters differ fundamentally from those of the particles that compose the turbidity standards. The range of particle sizes and shapes in formazin-based standards is similar to the diversity of particle sizes and shapes found in many real-world samples but cannot emulate site-specific color or particle-size distributions. The random nature of particle sizes and shapes across formazin standards yields statistically reproducible scatter on all turbidimeters (Sadar, 2003). All turbidity instruments are designed to produce equivalent responses to formazin, the industryaccepted standard, regardless of instrument specifications. However, concerns about the safety of the materials required to make formazin standards, potential for particles to settle, and accuracy when diluting formazin-based standards led to the introduction of commercially available styrene divinylbenzene polymer standards.

Polymer standards are commercially available in a range of concentrations and do not settle out of solution. They are made to be sensor specific, be stable, and require no preparation by the user. Additionally, they are nontoxic and have no special storage or disposal requirements (AMCOClear, 2020).

Despite the benefits of polymer standards, there are also concerns, including

- potential increases in calibration errors if the sensorspecific standards are used improperly,

- differences in polymer standards over time and between manufacturers, and

- potential environmental effects of microplastics.

In this study, YSI EXO turbidity sensors were evaluated by using both formazin and polymer standards to determine the variability between standards. Multiple lot numbers of polymer standards from the same manufacturer also were evaluated to determine the variability among lots.

Two individual turbidity sensors, the YSI EXO and YSI 6136, were compared as part of this study. The sensors operate on the same basic principles but differ in that one (YSI EXO) was updated and redesigned as a replacement for the older model (YSI 6136, used on the 6-Series instruments) that had been commercially available since 2002 . The manufacturer has noted a potential difference in values obtained by using the two sensors (Yellow Springs Instruments, 2012a, p. 7), both of which are still in use by the USGS:

"Since the optics of the EXO turbidity sensor is slightly different from those in the 6-Series system, it is likely that there will be a slight discontinuity in field readings taken with the two systems after calibration in the same laboratory standard. For example, differences in sediment readings of up to $10 \%$ at the same site are possible when transitioning between the 6-Series and EXO sensors with the EXO readings generally being lower in value."

The objectives of this study were to evaluate the response of two YSI turbidity sensors in both StablCal and polymer turbidity standards and to compare the YSI EXO and YSI 6136 turbidity sensors under similar laboratory and environmental conditions. These objectives were accomplished by determining

- the relative difference between YSI EXO and YSI 6136 turbidity sensors using the same calibration standard, in laboratory, and across a range of field conditions; 
- the relative differences for a given sensor using different calibration standards; and

- the relative difference between the same polymer bead standard for multiple lot numbers from the same manufacturer.

To quantify these differences, a series of laboratory and field side-by-side comparisons were conducted (table 1). Nine field comparisons of YSI EXO and YSI 6136 were performed at site locations in Kansas and Virginia. Two field comparisons of StablCal and polymer calibration standards were performed in Kansas, both using YSI EXO turbidity standards. Five laboratory comparisons between the YSI EXO and YSI 6136 turbidity sensors were performed, and seven laboratory comparisons between StablCal and polymer turbidity standards were performed using YSI EXO turbidity sensors (table 1). This report describes the methods used to conduct the comparisons and presents the results of those comparisons. Comparison results are presented in appendixes 1 through 23 (available for download at https://doi.org/10.3133/ofr20211009).

Table 1. Summary of the laboratory and field comparisons and associated appendixes that contain comparison descriptions and results.

[YSI, Yellow Springs Instruments]

\begin{tabular}{ccc}
\hline Comparison evaluated & $\begin{array}{c}\text { Field } \\
\text { comparisons }\end{array}$ & $\begin{array}{c}\text { Laboratory } \\
\text { comparisons }\end{array}$ \\
\hline $\begin{array}{c}\text { StablCal compared to poly- } \\
\text { mer turbidity calibration } \\
\text { standards }\end{array}$ & $\begin{array}{c}\text { Appendixes 1 } \\
\text { through 2 }\end{array}$ & $\begin{array}{c}\text { Appendixes 3 } \\
\text { through 9 }\end{array}$ \\
Multiple polymer calibration & Appendixes 10 & Appendixes 6 \\
standard lot numbers- & through 18 & through 9, \\
YSI EXO compared to YSI & & $\begin{array}{c}\text { appendixes 19 } \\
\text { through 23 }\end{array}$ \\
6136 turbidity sensor & & \\
\hline
\end{tabular}

\section{Instrument Technology Tested}

\section{Standards Used for Turbidity-Sensor Calibrations}

The two most common commercial calibration standards currently in use by the USGS were selected for comparative testing: Hach StablCal, a formazin-based primary standard, and a YSI polymer-based secondary standard. Formazin made from scratch is the primary turbidity standard referenced by the International Organization for Standardization (ISO) (ISO 7027; International Organization for Standardization, 1999) and the U.S. Environmental Protection Agency (EPA) (Method 180.1; U.S. Environmental Protection Agency, 1993). (An in-depth description of the physical and chemical properties of formazin can be found in Sadar [2003]). Hach StablCal has been stabilized for long shelf life and has reduced the exposure to the hazardous chemicals used in the creation of "scratch" formazin solutions (Sadar, 2003). Secondary standards are prepared by using polymer and then are referenced to a primary standard (ISO 7027; International Organization for Standardization, 1999) such as formazin. Secondary turbidity standards are typically made for a specific sensor and yield different readings when used with sensors other than those for which they were designed (Anderson, 2005). YSI recommends the use of its own polymer-based standard or formazin-based standards (YSI, 2016).

\section{Turbidity Sensors}

There are many commercially available turbidity sensors. Many of these sensors have ranges and accuracies tailored to observe common turbidity ranges in specific environments. A detailed discussion of turbidity sensors can be found in Rasmussen and others (2009), and different measurement methods, including the terms "nephelometric" and "ratiometric," are explained by Anderson (2005). Two instruments commonly used by the USGS, the YSI EXO turbidity sensor and the YSI 6136 turbidity sensor, were tested in this study. Typically, field-deployed sensor-based turbidity data are reported and stored as formazin nephelometric units (FNU) by the USGS in the National Water Information System (NWIS; parameter code 63680), as defined in ISO 7027 (International Organization for Standardization, 1999).

The YSI 6136 turbidity sensor (fig. 1) is a secondgeneration nephelometric, non-ratiometric turbidimeter that uses a light-emitting diode (LED) and is also ISO-7027 compliant. The emitted light has a wavelength in the range of 830 to 890 nanometers $(\mathrm{nm})$ and detects scattering at 90 degrees of the incident light beam. The YSI 6136 is a self-cleaning sensor with a built-in wiper used to avoid fouling and maintain accuracy. The YSI-specified operating range of the YSI 6136 sensor is 0 to 1,000 nephelometric turbidity units (NTU), 0.1 NTU resolution, and an accuracy of \pm 2 percent of reading or $0.3 \mathrm{NTU}$, whichever is greater (Yellow Springs Instruments, $2012 \mathrm{~b}$ ). Although the sensor method falls within the wavelength and incident light beam angle criteria to report data in FNU, the manufacturer maintained the NTU unit of measurement because it was commonly used when the YSI 6136 was developed and marketed (Yellow Springs Instruments, 2016). The maximum operating value, 1,000 NTU, is not a hard limit for the YSI 6136 sensor. Depending on individual sensor and suspension characteristics, the YSI 6136 can sometimes yield measurements much higher than 1,000 NTU, although the accuracy and resolution of these readings are uncertain.

The YSI EXO turbidity sensor (fig. 2) is characterized as a nephelometric near-infrared turbidimeter, and is ISO 7027-compliant, which requires that turbidity values be reported in FNU. The sensor uses a near-infrared light source $(845-875 \mathrm{~nm})$ and detects scattering at 90 degrees of the incident light beam. The YSI-specified operating range of the 


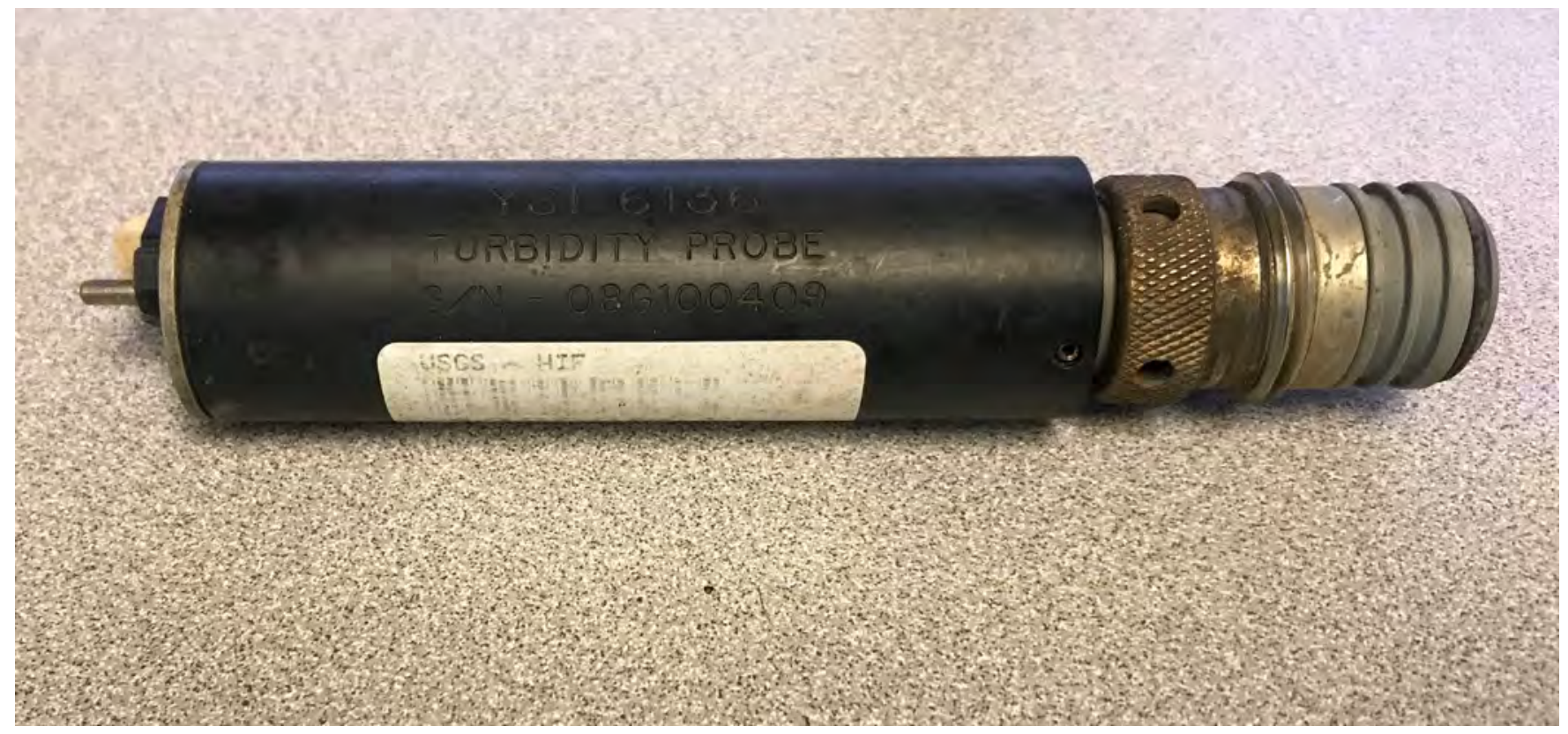

Figure 1. Yellow Springs Instruments (YSI) 6136 turbidity sensor. Photograph by U.S. Geological Survey.

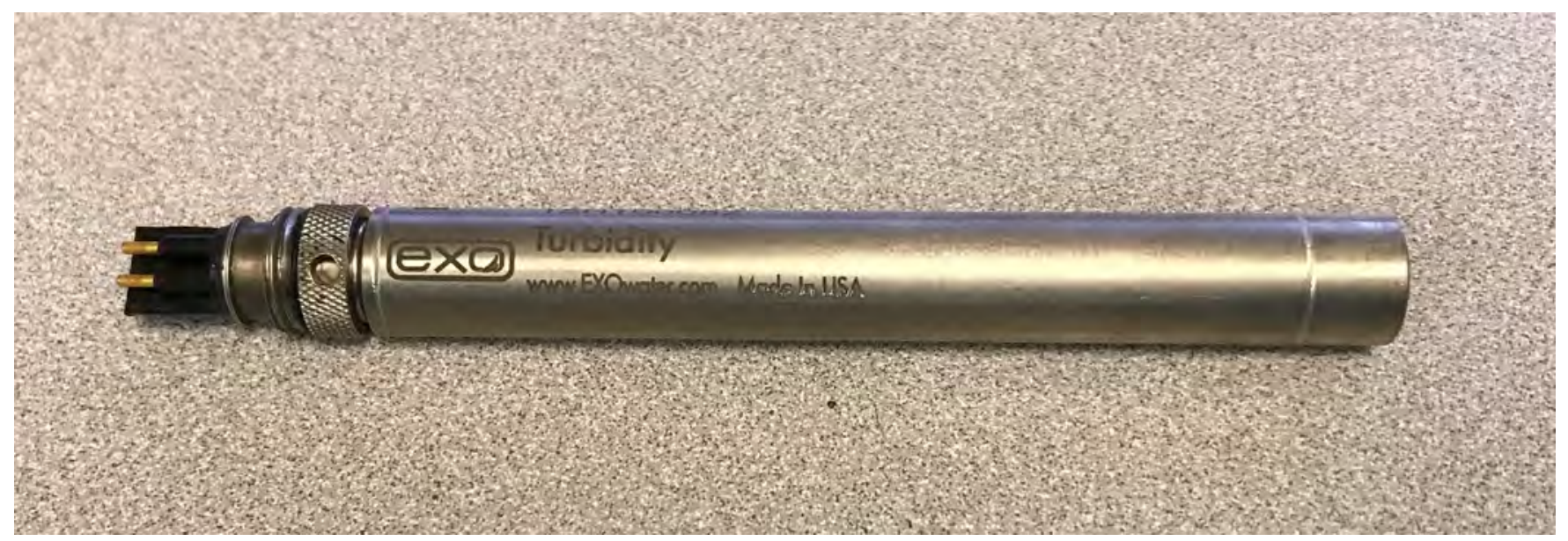

Figure 2. Yellow Springs Instruments (YSI) EXO turbidity sensor. Photograph by U.S. Geological Survey.

YSI EXO sensor is 0 to 4,000 FNU with 0.01 FNU resolution from 0 to $999 \mathrm{FNU}$ and $0.1 \mathrm{FNU}$ resolution from 1,000 to $4,000 \mathrm{FNU}$. The accuracy of the YSI EXO turbidity sensor is \pm 2 percent of the measurement or $0.3 \mathrm{FNU}$, whichever is greater, from 0 to $999 \mathrm{FNU}$, and \pm 5 percent from 1,000 to 4,000 FNU (Yellow Springs Instruments, 2017). To reduce fouling, the YSI EXO turbidity sensor can utilize an external wiper when deployed, which is designed to wipe all deployed sensors when using selected YSI EXO sondes.

The Hach Model 2100AN laboratory turbidimeter (fig. 3) is a benchtop turbidimeter that is EPA Method 180.1-compliant (Hach, 2013). The Hach 2100AN measures turbidity from 0 to 10,000 NTU by simultaneously measuring the ratio of responses at 90 degrees, forward scatter and backscatter, and transmitted light through a cuvette using a tungsten lamp (Hach, 2013). Currently (2018), the Hach 2100AN is used by the USGS National Water Quality Laboratory (NWQL) for turbidity measurements (Van Valkenburg and others, 2016). For measurements in samples of natural water with coarse sediment particles (such as sand), a flow cell is used to keep particles suspended in the measurement cuvette (Van Valkenburg and others, 2016). Because the Hach 2100AN uses a ratio of responses, it is reported by the USGS in nephelometric turbidity ratio units (NTRU) (NWIS parameter code 63676). For this study, the Hach Model 2100AN laboratory turbidimeter was used as a reference and the values from this turbidimeter were considered "reference" values when comparing standards and sensors; therefore, values were reported in FNU. 


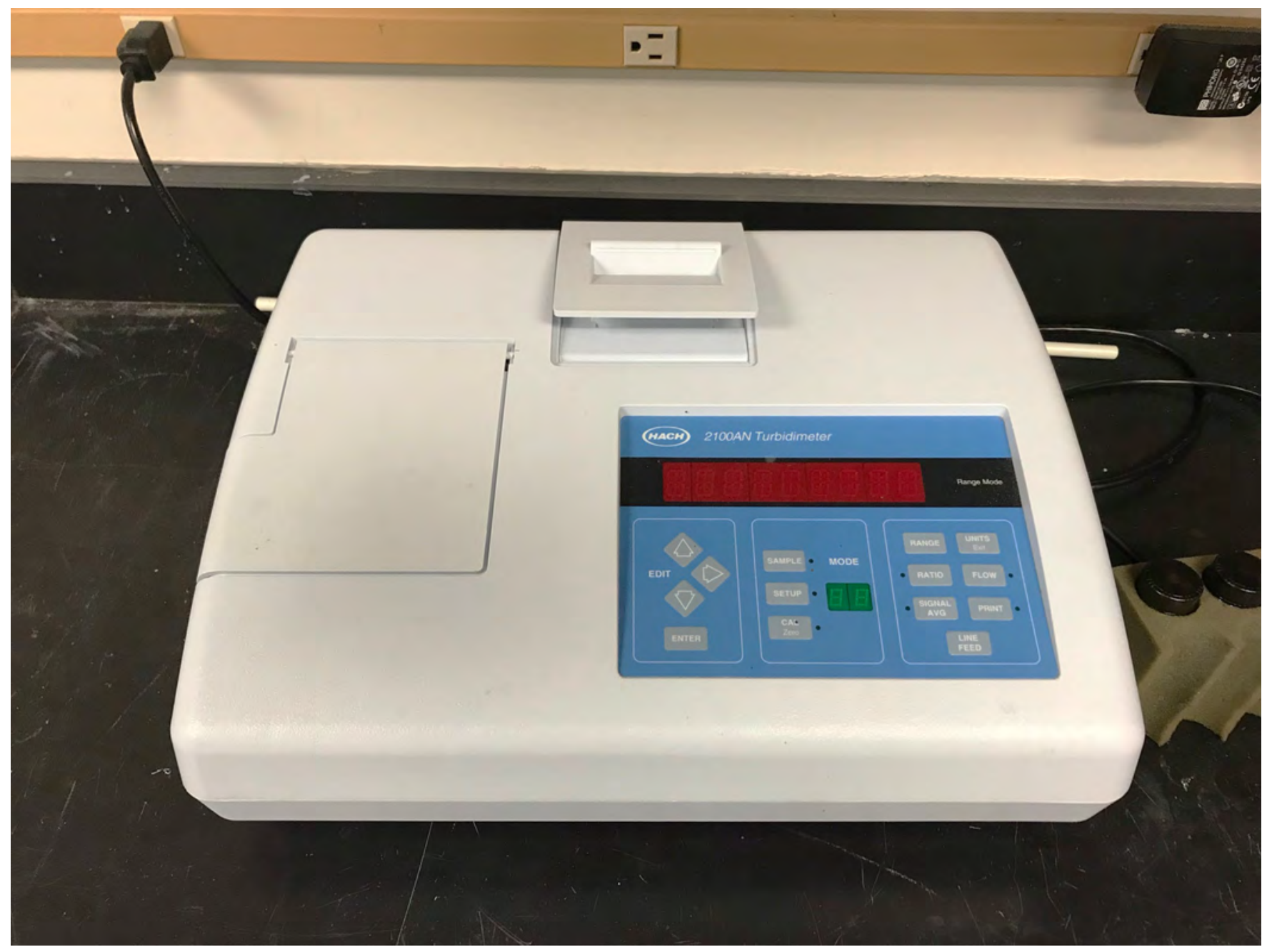

Figure 3. Hach Model 2100AN laboratory turbidimeter. Photograph by U.S. Geological Survey.

\section{Performance Evaluation Tests}

\section{Calibration Standard Comparison Tests}

Testing of calibration standards was designed to answer two questions: (1) what is the relative difference in turbidity values when the same sensor model is calibrated by using different calibration standards (StablCal and YSI polymer), and (2) what is the among-lot variability of polymer in standards from the same manufacturer? Standard comparisons were conducted in the laboratory by using natural sediment in natural water and commercially available clay in deionized water. Side-by-side field comparisons also were conducted to compare sensors under natural conditions. The YSI EXO turbidity sensors were used for comparisons of calibration standards (table 1).

\section{Sensor Comparison Tests}

Sensor comparison tests were designed to (1) assess how the YSI EXO and YSI 6136 sensors performed under different sediment (laboratory) and environmental (field) conditions when calibrated by using the same standards; and (2) determine whether observed differences were comparable across a range of sediment and environmental conditions. Sensor comparisons were conducted in the laboratory by using natural sediment in natural water and commercially available clay in deionized water. Side-by-side field comparisons also were conducted to compare sensors under natural conditions (table 1). Both calibration standard types were used under field conditions; however, all turbidity-sensor pairs at individual sites were calibrated with the same calibration standard.

Ideally, sensor comparisons conducted for any reason would compare sensor response in the identical parcel of water at exactly the same time. While ideal, this is a practical impossibility as a result of the physical limitations of turbidity sensors and the nature of the suspended particles. These limitations are especially problematic in side-by-side 
field comparisons, as natural suspended-sediment concentrations are rarely perfectly uniform across a cross section, and differences in sensor mounting can have subtle effects on measurements. In addition, the exact cause of the potentially small differences between sensors or standards (for example, sensor differences, or the aforementioned variability) becomes increasingly uncertain because of differences in sensor response (between the YSI EXO and YSI 6136 through differences in operation and user settings) and fouling rate (both biological and sediment fouling can vary between the YSI EXO and YSI 6136 as a result of differences in sensor face material or wiping mechanism, as well as normal biological variability). These challenges were minimized as much as was practical in both field and laboratory comparisons by mounting sensors as close together as possible and minimizing time between cleanings.

\section{Testing Materials}

For laboratory tests (conducted at the USGS Kansas Water Science Center water-quality laboratory in Lawrence, Kansas), natural sediments (collected from various field sites in Kansas) and commercially available clays, natural water (collected from field sites), and laboratory water (tap and deionized water) were used for various tests (app. 1-23, at the end of this report). Sediment from each field site was collected from within the uppermost 2 inches of the streambank or streambed into a glass container. Sediment was collected from areas with primarily fine sediment (determined qualitatively by visual and tactile assessment) so that it could be easily suspended in a secondary container. Water from each site was collected by submerging a plastic carboy at the water surface. Water was collected during low-flow periods when turbidities at each site were relatively low (less than $30 \mathrm{FNU}$ ). Sediment and water were refrigerated until use.

Three differently colored (white, pink, and black) laboratory-grade kaolinite clays were used in experiments to determine whether sediment color affected data comparability between turbidity sensors and standards. Kaolinite is a secondary mineral formed by alteration of aluminum silicates (generally feldspars), typically at shallow depths in soils and rocks near the surface (Chesterman, 1978).

\section{Quality-Assurance Calibration Checks of Turbidity Sensors and Quality Assurance of Calibration Standards}

Before each experiment (laboratory or field), calibration checks were performed on the turbidity sensors by using StablCal or YSI polymer standards, depending on which standard was being tested. Zero turbidity was checked by using deionized water for all experiments. For StablCal, standards of $100 \mathrm{FNU}$ and 1,000 FNU were used to bracket the range of expected conditions. For polymer standards, the standards 124 and 1,010 FNU, respectively, for the YSI EXO sensor and 126 and 1,000 FNU, respectively, when using the YSI 6136 sensor. If sensor calibration was not within \pm 0.5 turbidity units or \pm 5 percent (whichever is greater) of the standard concentration (Wagner and others, 2006), the sensor was recalibrated by following manufacturer specifications.

The calibration of the Hach 2100AN turbidimeter was checked by using a turbidity solid-standard calibration kit following manufacturer specifications. The kit included six standards with concentrations of less than $0.1,20,200,1,000$, 4,000 , and 7,500 NTU. The "Ratio" mode was used for all calibrations. This approach provides good linearity, calibration stability, and wide measurement range, and helps correct for interference when color that absorbs at the wavelength of incident light is present in the sample (Hach, 2014).

All turbidity standards used were first measured in the Hach 2100AN to verify standard concentration. Standards were inverted in the bottle three times, then poured into a glass sample cell. A lint-free cloth was used to clean the outside of the sample cell to remove dust particles, water spots, fingerprints, and anything else that could potentially affect the measurement. The sample cell was placed in the sample cell holder, and the lid was shut to remove all light interference. Standard concentrations were recorded after the instrument readings stabilized, typically after a few minutes.

Hach 2100AN measurements were not expected to match polymer standard concentrations as labeled because polymer standards are customized for a specific sensor. However, Hach 2100AN readings were considered to be useful to assess the consistency of polymer calibration standards among lots. Typically, readings for the 124-FNU standard readings ranged from 106 to $109 \mathrm{FNU}$ in the Hach 2100AN, and the $1,010 \mathrm{FNU}$ standard readings ranged from 723 to $737 \mathrm{FNU}$ in the Hach 2100AN (table 2). The YSI 1,010 polymer standard label notes a third sensor ("Viso Turb"), with an FNU value of 720. Because this value was closest to the $2100 \mathrm{AN}$ readings, it was used as the reference concentration for measurements with the Hach 2100AN. During verification of the polymer standards in the Hach 2100AN, the RPD for the 124-FNU standard ranged from 13 to 16 percent (mean RPD of 14 percent) and the RPD for the 720-FNU (1,010 FNU for YSI EXO; 1,000 FNU for YSI 6136) standard ranged from 0 to 2 percent (mean RPD of 2 percent). The Hach 2100 AN was expected to read $100 \mathrm{FNU}$ and 1,000 FNU when measuring the StablCal standards. Typically, readings for the 100-FNU StablCal standard ranged from 95 to $99.2 \mathrm{FNU}$ and for the 1,000-FNU StablCal standard ranged from 960 to 1,028 FNU in the Hach 2100AN (table 2). During verification of StablCal standards in the Hach 2100AN, the RPD for the 100-FNU standard ranged from 1 to 5 percent (mean RPD of 3 percent) and the RPD for the 1,000 FNU standard ranged from 0 to 4 percent (mean RPD of 2 percent).

During the calibration checks, turbidity standards were reused for the rinses. The concentration of each standard that was reused was verified in the Hach 2100AN prior to use as a rinse. During a calibration check, the turbidity sensor was rinsed three times with reused standards, and the final check was performed with new standard of the same lot number that was verified in the Hach 2100AN before it was used as a check. 
Table 2. Standard verification measurements made with the Hach 2100AN turbidimeter.

[NTU, nephelometric turbidity units; NTRU, nephelometric turbidity ratio units]

\begin{tabular}{|c|c|c|c|c|}
\hline $\begin{array}{l}\text { Standard } \\
\text { verifica- } \\
\text { tion date }\end{array}$ & Standard & $\begin{array}{c}\text { Standard } \\
\text { concen- } \\
\text { tration } \\
\text { (NTU) }^{1} \\
\end{array}$ & $\begin{array}{c}\text { Hach } \\
\text { 2100AN } \\
\text { measure- } \\
\text { ment (NTRU) }\end{array}$ & $\begin{array}{l}\text { Relative } \\
\text { percent- } \\
\text { age differ- } \\
\text { ence }^{2}\end{array}$ \\
\hline $2 / 8 / 2017$ & Hach StablCal & 100 & 98.5 & 2 \\
\hline $3 / 1 / 2017$ & Hach StablCal & 100 & 99.1 & 1 \\
\hline $2 / 15 / 2017$ & Hach StablCal & 100 & 99.2 & 1 \\
\hline 2/7/2017 & Hach StablCal & 100 & 97.8 & 2 \\
\hline $1 / 31 / 2017$ & Hach StablCal & 100 & 99 & 1 \\
\hline $3 / 24 / 2017$ & Hach StablCal & 100 & 98.9 & 1 \\
\hline $3 / 21 / 2017$ & Hach StablCal & 100 & 95 & 5 \\
\hline $3 / 28 / 2017$ & Hach StablCal & 100 & 96.6 & 3 \\
\hline 9/6/2017 & Hach StablCal & 100 & 95.5 & 5 \\
\hline $9 / 13 / 2017$ & Hach StablCal & 100 & 95.5 & 5 \\
\hline $9 / 15 / 2017$ & Hach StablCal & 100 & 95.2 & 5 \\
\hline 2/8/2017 & Hach StablCal & 1,000 & 960 & 4 \\
\hline $3 / 1 / 2017$ & Hach StablCal & 1,000 & 1,006 & 1 \\
\hline $2 / 15 / 2017$ & Hach StablCal & 1,000 & 1,014 & 1 \\
\hline 2/7/2017 & Hach StablCal & 1,000 & 1,019 & 2 \\
\hline $1 / 31 / 2017$ & Hach StablCal & 1,000 & 986 & 1 \\
\hline $3 / 24 / 2017$ & Hach StablCal & 1,000 & 987 & 1 \\
\hline $3 / 21 / 2017$ & Hach StablCal & 1,000 & 984 & 2 \\
\hline $3 / 28 / 2017$ & Hach StablCal & 1,000 & 1,028 & 3 \\
\hline 9/6/2017 & Hach StablCal & 1,000 & 984 & 2 \\
\hline $9 / 6 / 2017$ & Hach StablCal & 1,000 & 994 & 1 \\
\hline $9 / 15 / 2017$ & Hach StablCal & 1,000 & 997 & 0 \\
\hline $9 / 6 / 2017$ & YSI Polymer & 124 & 108 & 14 \\
\hline $9 / 6 / 2017$ & YSI Polymer & 124 & 107 & 15 \\
\hline $9 / 13 / 2017$ & YSI Polymer & 124 & 108 & 14 \\
\hline $9 / 13 / 2017$ & YSI Polymer & 124 & 108 & 14 \\
\hline $9 / 13 / 2017$ & YSI Polymer & 124 & 106 & 16 \\
\hline $9 / 15 / 2017$ & YSI Polymer & 124 & 109 & 13 \\
\hline $9 / 15 / 2017$ & YSI Polymer & 124 & 107 & 15 \\
\hline $9 / 15 / 2017$ & YSI Polymer & 124 & 106 & 16 \\
\hline $9 / 6 / 2017$ & YSI Polymer & 720 & 731 & 2 \\
\hline 9/6/2017 & YSI Polymer & 720 & 732 & 2 \\
\hline 9/13/2017 & YSI Polymer & 720 & 735 & 2 \\
\hline $9 / 13 / 2017$ & YSI Polymer & 720 & 737 & 2 \\
\hline 9/13/2017 & YSI Polymer & 720 & 732 & 2 \\
\hline $9 / 15 / 2017$ & YSI Polymer & 720 & 723 & 0 \\
\hline $9 / 15 / 2017$ & YSI Polymer & 720 & 734 & 2 \\
\hline $9 / 15 / 2017$ & YSI Polymer & 720 & 734 & 2 \\
\hline
\end{tabular}

'Standard concentration "720" was noted on the label for a "Viso Turb" sensor. Because this value was closest to the $2100 \mathrm{AN}$ reading, it was used as the reference concentration for quality-assurance purposes.

${ }^{2}$ Relative percentage difference (RPD) was used to evaluate differences in concurrently collected turbidity measurements. The RPD was calculated by dividing the absolute difference between replicate pairs by the mean and multiplying that value by 100 , thereby creating a value that represents the percent difference between paired samples (Zar, 1999).

\section{Laboratory Tests}

A simple laboratory testing apparatus was developed for this study based on the design of Lewis and others (2007) (figs. 4-5). Materials for the testing apparatus included the following:

- alternating current (AC) electric drill with locking trigger, to keep particles in suspension

- paint-stirring attachment, helix style

- black 5-gallon bucket with lid (figs. 4-5)

- chemistry stand with clamps to mount drill

- hose clamps and foam strips to mount sondes suspended above the bottom of the bucket (about 1 inch)

At the beginning of each test, sensors were placed in deionized water or natural water from a field site. The electric drill was turned on to mix and suspend sediments. Because steady-state readings were the ideal condition for the planned analysis, it was not important that all sediments were suspended, but it was important that steady-state conditions were achieved, ideally through a uniform suspension. The difficulty of achieving a uniform suspension depended on the material used, with uniform suspensions being more easily achieved in homogeneous than heterogeneous materials. The internal clock of each sensor was synchronized and set to self-log every 10 seconds. A minimum of 10 minutes was allowed to pass in order for any suspended particles to reach a steady state for each step of data collection. After steady-state conditions were achieved, as determined from live sensor readings, a sample was collected near the sensors with a peristaltic pump and the flow-through cell. The sample was analyzed in the Hach 2100AN turbidimeter, and the value and time were recorded. Approximately 0.5 to 2 tablespoons of solid suspendible material was added to the bucket (the amount varied and was based on the material and its effect on turbidity), and at least another 10 minutes was allowed to pass before the next sample was collected and analyzed in the Hach 2100AN. This process was repeated until sensor readings reached their maximum limit and were truncated. Typical results followed the pattern shown in figure 6.

\section{Field Tests}

Sensor comparison tests were conducted at nine sites in Kansas and Virginia, and standard comparison tests were conducted at two sites in Kansas (fig. 7); tests lasted from 2 weeks to 9 months (tables 3 and 4). Data were collected at 15-minute intervals. Sensor comparison sites included Little Arkansas River at Highway 50 near Halstead, Kansas; Little Arkansas River near Sedgwick, Kansas; North Fork Ninnescah River above Cheney Reservoir, Kansas; Cheney Reservoir near Cheney, Kansas; Neosho River at Neosho Rapids, Kansas; Neosho River at Burlington, Kansas; Mill Creek at Johnson 


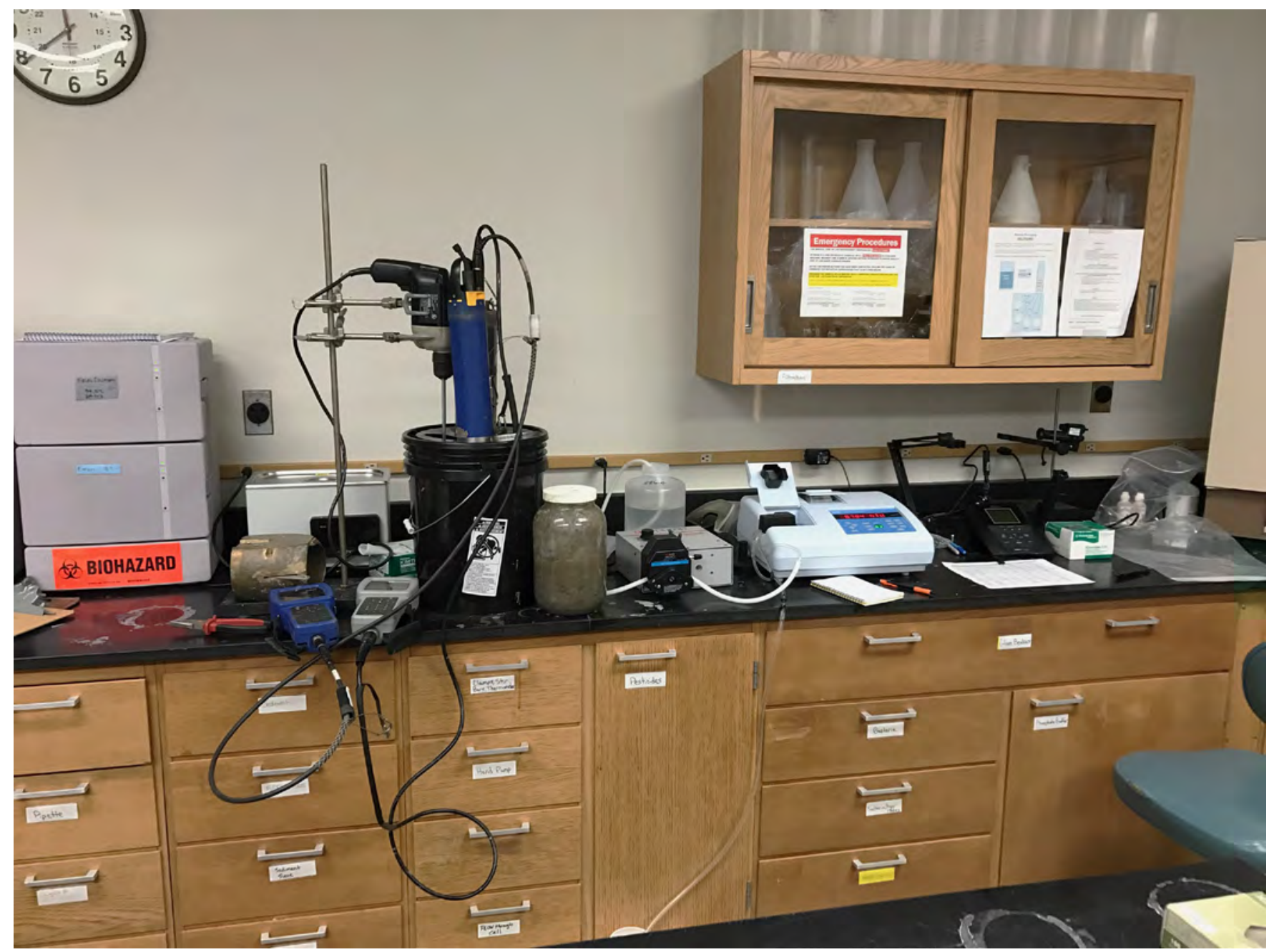

Figure 4. Laboratory turbidity testing apparatus and benchtop turbidimeter. Photograph by U.S. Geological Survey.

Drive, Shawnee, Kansas; James River at Cartersville, Virginia; and Difficult Run above Fox Lake near Fairfax, Virginia (table 3). Standard comparison sites included Neosho River at Burlingame Road near Emporia, Kansas, and Kansas River at De Soto, Kansas (table 4).

Field testing allows for observation of sensor response over the wide range of conditions experienced in the natural environment. However, variability not directly related to differences in turbidity sensors or calibration standards can be observed in side-by-side field deployments, including fouling at different rates, effect of different time averaging (a userset method of averaging sensor readings available to reduce erroneous readings) during rapidly changing conditions, and differences in the turbidity of the measured volume for each sensor.

To minimize fouling variability, some of the Kansas field side-by-side comparisons were deployed during storm events and then retrieved when turbidity values and flow conditions returned to base flow. Side-by-side deployments of the sensors began when turbidity values were relatively high during the receding limb of the hydrograph. Other side-by-side deployments were conducted over a predetermined period of time. In each case, water-quality monitors were placed as close together as possible (strapped together in some cases) and set to log simultaneously. For field comparisons between StablCal- and polymer-calibrated sensors, two YSI EXO turbidity sensors, one calibrated in each standard, were attached to the same YSI EXO water-quality monitor body, on opposite sides of the sensor bulkhead and central wiper, to minimize sensor-to-sensor interferences. The resulting data were divided into low- and high-turbidity conditions. For the purposes of this study, low turbidity (0-99 FNU) captured base-flow/steady-state conditions, whereas high turbidity (greater than $100 \mathrm{FNU}$ ) was representative of high-load/ high-variability conditions.

\section{Data Analysis}

Field-collected data were analyzed in three ways: (1) the entire dataset with only clearly erroneous data edited as determined on the basis of guidance presented in Wagner and 


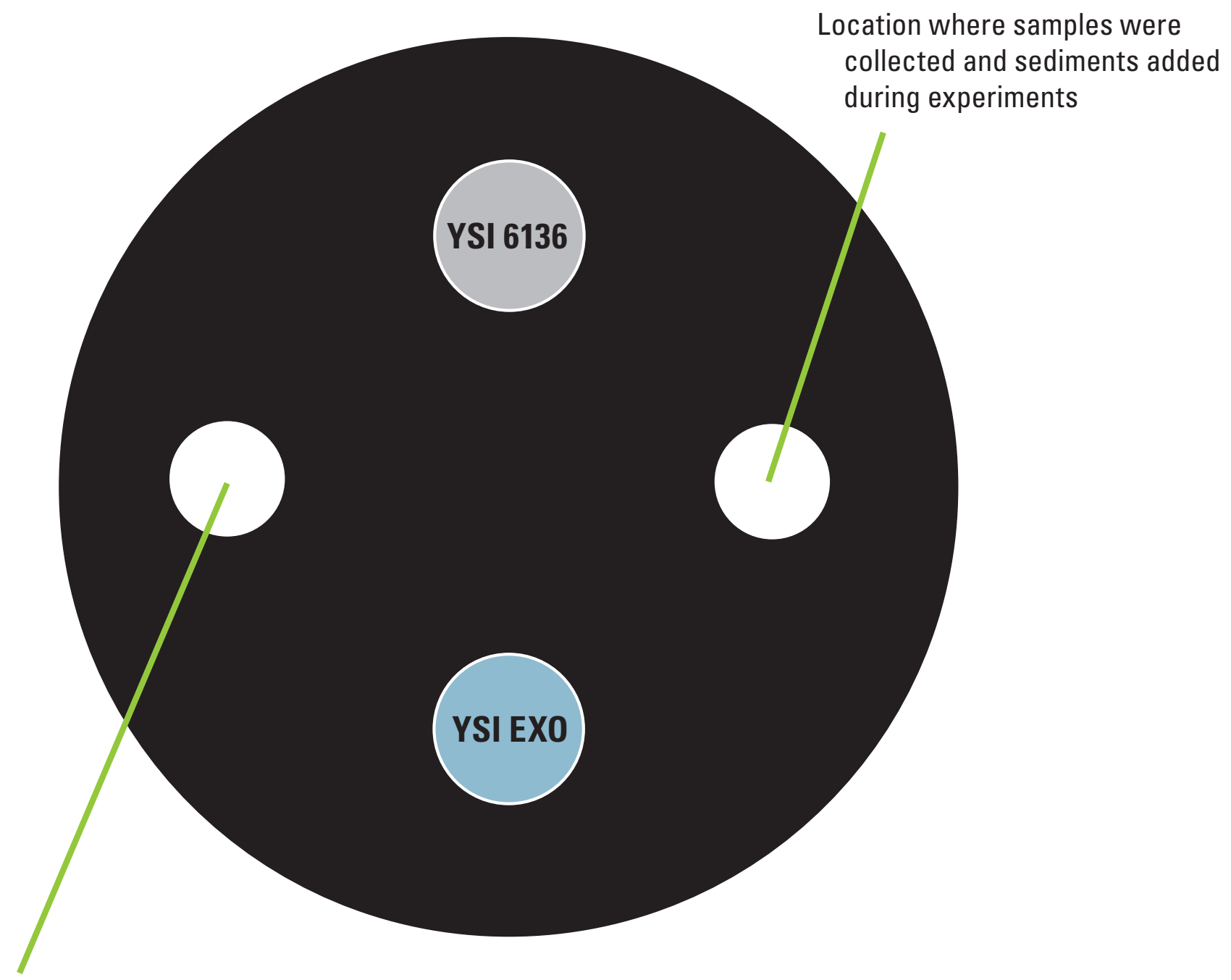

Location where the electric drill stirrer was placed to stir up sediments in the bucket

Figure 5. Generalized lid configuration for laboratory testing apparatus. YSI 6136, Yellow Springs Instruments 6136 turbidity sensor; YSI EXO, Yellow Springs Instruments EXO turbidity sensor. 


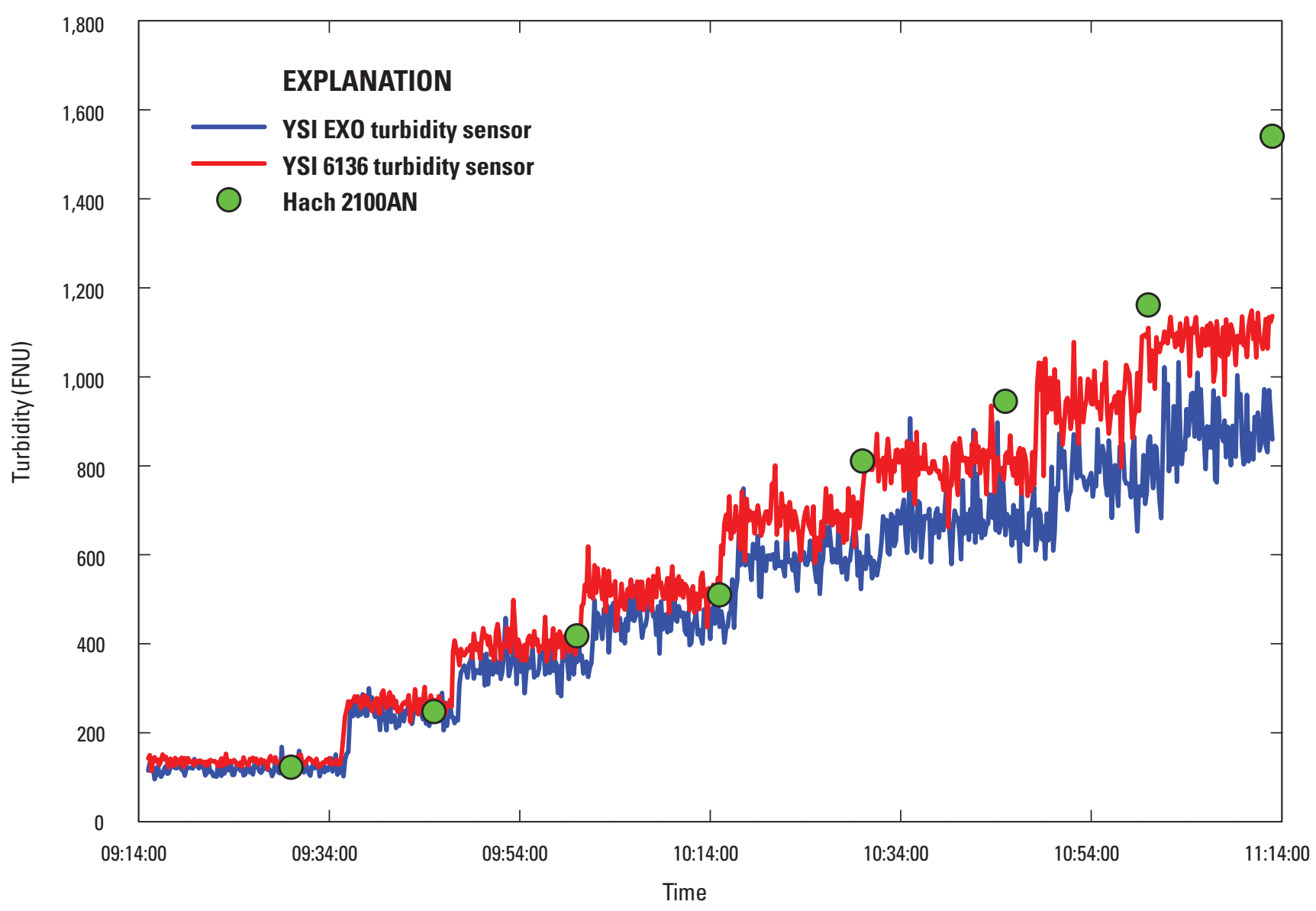

Figure 6. Generalized pattern of results of laboratory turbidity tests using Yellow Springs Instruments EXO and 6136 turbidity sensors and the HACH 2100AN turbidimeter. FNU, formazin nephelometric units.

others (2006), (2) 0-99 FNU (read on the YSI 6136) with rising limbs removed, and (3) 100-1,000 FNU with rising limbs removed. The break at $100 \mathrm{FNU}$ was chosen to separate relatively steady-state turbidity data and high-turbidity conditions indicative of greater sediment loads associated with storm events. This break was adequate for the datasets being analyzed; however, if similar analyses were conducted in other locations, especially where turbidity ranges were small, a different breakpoint would likely need to be chosen. For the purposes of comparing the probes and different calibration methods, rising limbs were removed (as determined on the basis of visual inspection, when plots of the data became vertical to near-vertical) to eliminate the effect of potentially highly variable turbidity readings typically experienced during those events. In a similar fashion, laboratory data were edited to remove periods during which material was added to the testing apparatus, leaving the relatively steady-state data for analysis. The response of the YSI EXO turbidity sensor greater than 1,000 FNU was not analyzed, because the upper limit of measurements made with the YSI 6136 turbidity sensor is 1,000 FNU. In laboratory experiments, however, measurements greater than $1,000 \mathrm{FNU}$ were collected with the YSI EXO turbidity sensor (with corresponding Hach 2100AN data). All data presented in this report are available in King (2021) as a USGS data release. Analysis of measurements greater than 1,000 FNU was beyond the scope of this report but is included with the data release for potential future use.

For each set of comparative data, a Shapiro-Wilk normality test was performed (Helsel and Hirsch, 2002). If the data passed and were normally distributed, a paired $t$-test was performed to determine whether the average differences between the YSI EXO and YSI 6136 turbidity sensor readings were statistically significant. If the normality test failed, then a nonparametric Wilcoxon signed-rank test was performed to determine whether the median differences were statistically significant (Helsel and Hirsch, 2002). In one case, the extremely large number of data points $(n=24,280)$ warranted use of the Kolmogorov-Smirnov test (Sokal and Rohlf, 1995) instead of the Shapiro-Wilk test. Tests were performed with the statistical software packages SigmaPlot (Shapiro-Wilk, paired t-tests, Wilcoxon signed-rank tests, and Kolmogorov-Smirnov; Systat Software, Inc., 2008) and R (confidence interval for Wilcoxon signed-rank tests; R Core Team, 2015).

Pearsons's R, or correlation coefficient, was used to compute the linear association between paired data points (Helsel and Hirsch, 2002). For this analysis, $R$ values from 1.0 to 

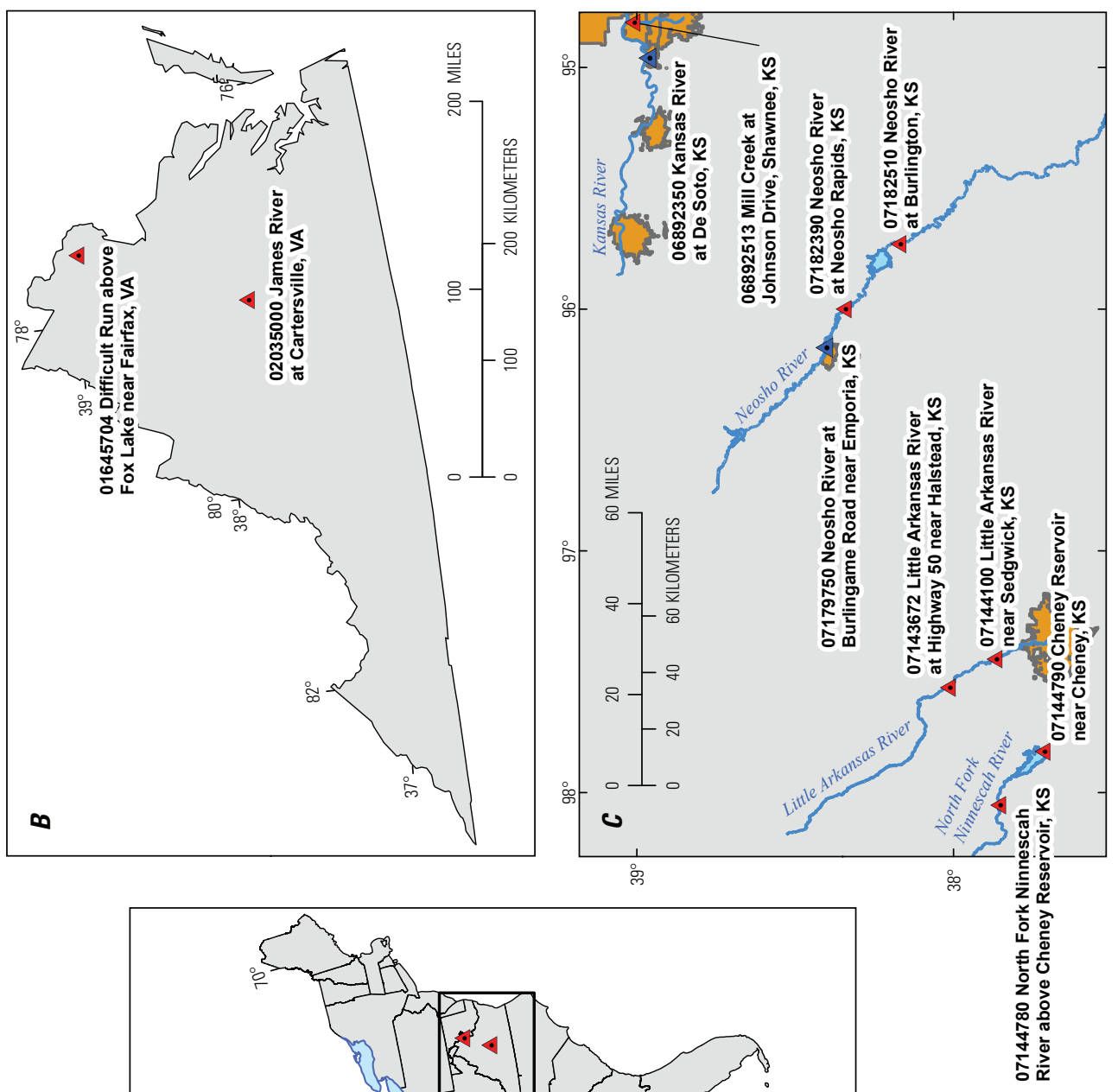

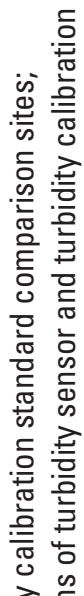

흘을

辛 으

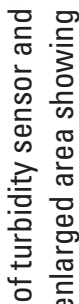

ᄃิ v

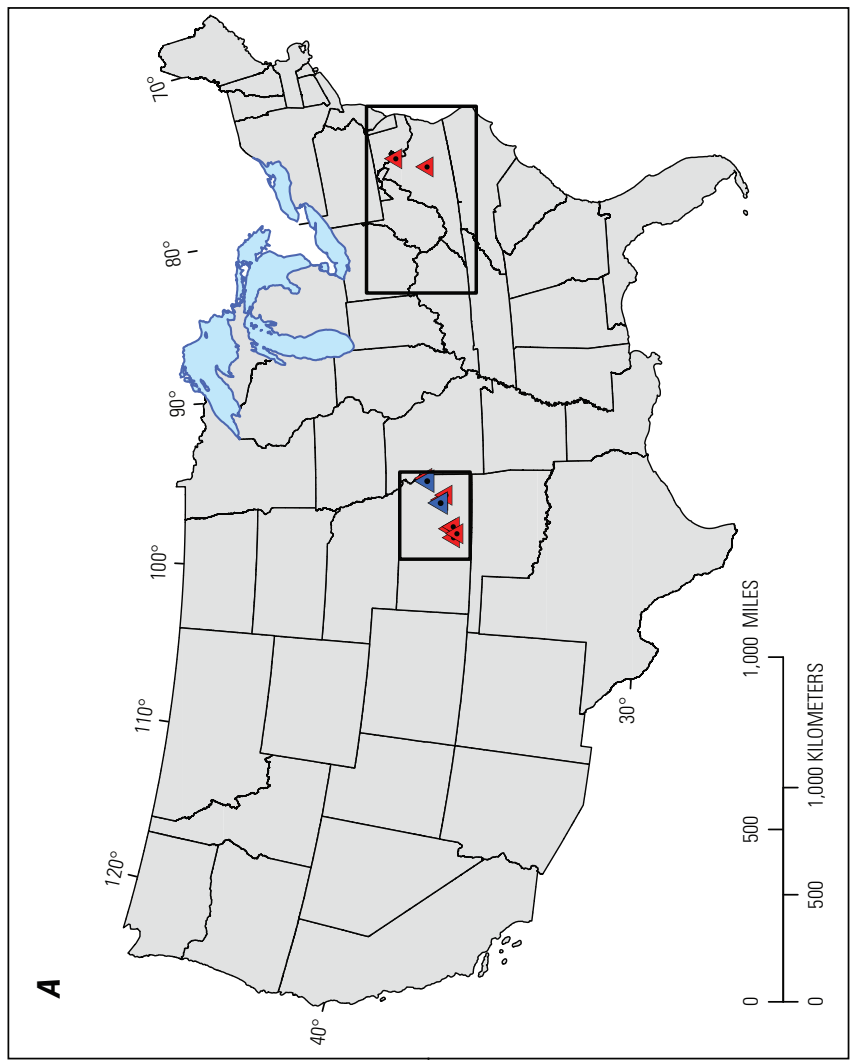

鸪

ष

$\stackrel{\infty}{ \pm}$

ธิ

迹 $\frac{\Phi}{\omega}$

है ธ

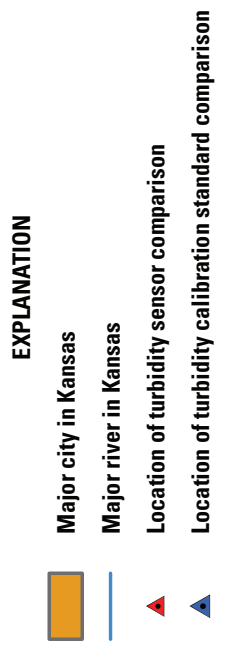

0

힌 을

完

㐘

들 윻

휸

흘

筞司

츰

言哭嵒

물 흉

๘

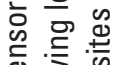

¿ 3

这它.

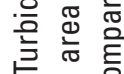

$\vdash$ 웡

동ㅎㅇ

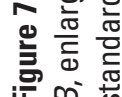


Table 3. Site locations for field turbidity sensor comparison tests.

[Each test utilized one each EXO turbidity sensor and 6136 turbidity sensor. YSI, Yellow Springs Instruments]

\begin{tabular}{lcll}
\hline \multicolumn{1}{c}{ Station name } & Site identifier & \multicolumn{1}{c}{ Duration of comparison } & \multicolumn{1}{c}{$\begin{array}{c}\text { Standards used for } \\
\text { comparison }\end{array}$} \\
\hline Little Arkansas River at Highway 50 near Halstead, Kansas & 07143672 & January 25-June 28, 2017 & YSI polymer \\
Little Arkansas River near Sedgwick, Kansas & 07144100 & March 30-June 28, 2017 & $\begin{array}{l}\text { YSI polymer } \\
\text { YSI polymer }\end{array}$ \\
$\begin{array}{l}\text { North Fork Ninnescah River above Cheney Reservoir, } \\
\quad \text { Kansas }\end{array}$ & 07144780 & March 31-June 7, 2017 & \\
Cheney Reservoir near Cheney, Kansas & 07144790 & October 1, 2014-March 12, 2015 & YSI polymer \\
Neosho River at Neosho Rapids, Kansas & 07182390 & April 4-May 9, 2017 & Hach StablCal \\
Neosho River at Burlington, Kansas & 07182510 & May 9-May 16, 2017 & Hach StablCal \\
Mill Creek at Johnson Drive, Shawnee, Kansas & 06892513 & August 16-August 31, 2017 & Hach StablCal \\
James River at Cartersville, Virginia & 02035000 & October 7, 2016-July 10, 2017 & Hach StablCal \\
Difficult Run above Fox Lake near Fairfax, Virginia & 01645704 & May 6-July 25, 2017 & Hach StablCal \\
\hline
\end{tabular}

Table 4. Site locations for field turbidity standard comparison tests.

[Each test utilized two EXO turbidity sensors. YSI, Yellow Springs Instruments]

\begin{tabular}{lclc}
\hline \multicolumn{1}{c}{ Station name } & Site identifier & Duration of comparison & Standards used for comparison \\
\hline Neosho River at Burlingame Road near Emporia, Kansas & 07179750 & May 16-June 27, 2017 & $\begin{array}{c}\text { One calibrated in Hach StablCal and } \\
\text { one calibrated in YSI polymer }\end{array}$ \\
Kansas River at De Soto, Kansas & 06892350 & May 16-June 24, 2017 & $\begin{array}{c}\text { One calibrated in Hach StablCal and } \\
\text { one calibrated in YSI polymer }\end{array}$ \\
\hline
\end{tabular}

0.70 were considered strong correlations; from 0.70 to 0.50 , moderate correlations; and from 0.50 to 0.30 , weak correlations. $R$ values less than 0.30 were not encountered but would have been considered to have no linear correlation. Absolute difference and RPD were used to evaluate differences in concurrently collected turbidity measurements. The RPD was calculated by dividing the absolute difference between replicate pairs by the mean and multiplying that value by 100 , yielding a value that represents the percent difference between paired samples (Zar, 1999). For the purposes of this study, paired samples with an RPD within 10 percent or less were considered acceptable on the basis of the YSI web release statement that the YSI EXO turbidity sensor should read less than 10 percent lower than the YSI 6136 turbidity sensor (Yellow Springs Instruments, 2012a). For uniformity, this 10-percent threshold also was used to assess differences between turbidity standards. Additionally, a 30-percent threshold was used for evaluation because it is used as the maximum allowable error for field turbidity data in Wagner and others (2006), the USGS standard methods reference for collecting continuous field turbidity data. For field-collected continuous turbidity data, duration curves were developed for RPD analysis to determine the percentage of the data that fell above or below thresholds of interest.

\section{Results of Calibration Standard Comparison Tests}

Results of field comparison tests between StablCal- and polymer-calibrated YSI EXO turbidity sensors are provided in table 5 and appendixes 1 and 2. Results of laboratory comparison tests between StablCal- and polymer-calibrated turbidity sensors are provided in table 6 and appendixes 3 to 9 . A strong linear correlation ( $R$ greater than 0.70 ) was found between the StableCal- and polymer-calibrated YSI EXO turbidity sensors in all tests under both field and laboratory conditions (tables 5 and 6). However, linear associations were not necessarily 1:1, and the slope of the relation varied between laboratory and field comparisons. The bias observed between StableCal- and polymer-calibrated YSI EXO turbidity measurements was not consistent among lot, laboratory, or field comparisons. For example, at two field sites, the relation between the StablCal and polymer groups was biased slightly high at one site and slightly low at another (fig. $8 A$ ). In some laboratory comparisons, the direction of bias changed across the range of turbidity conditions (fig. 9A). 


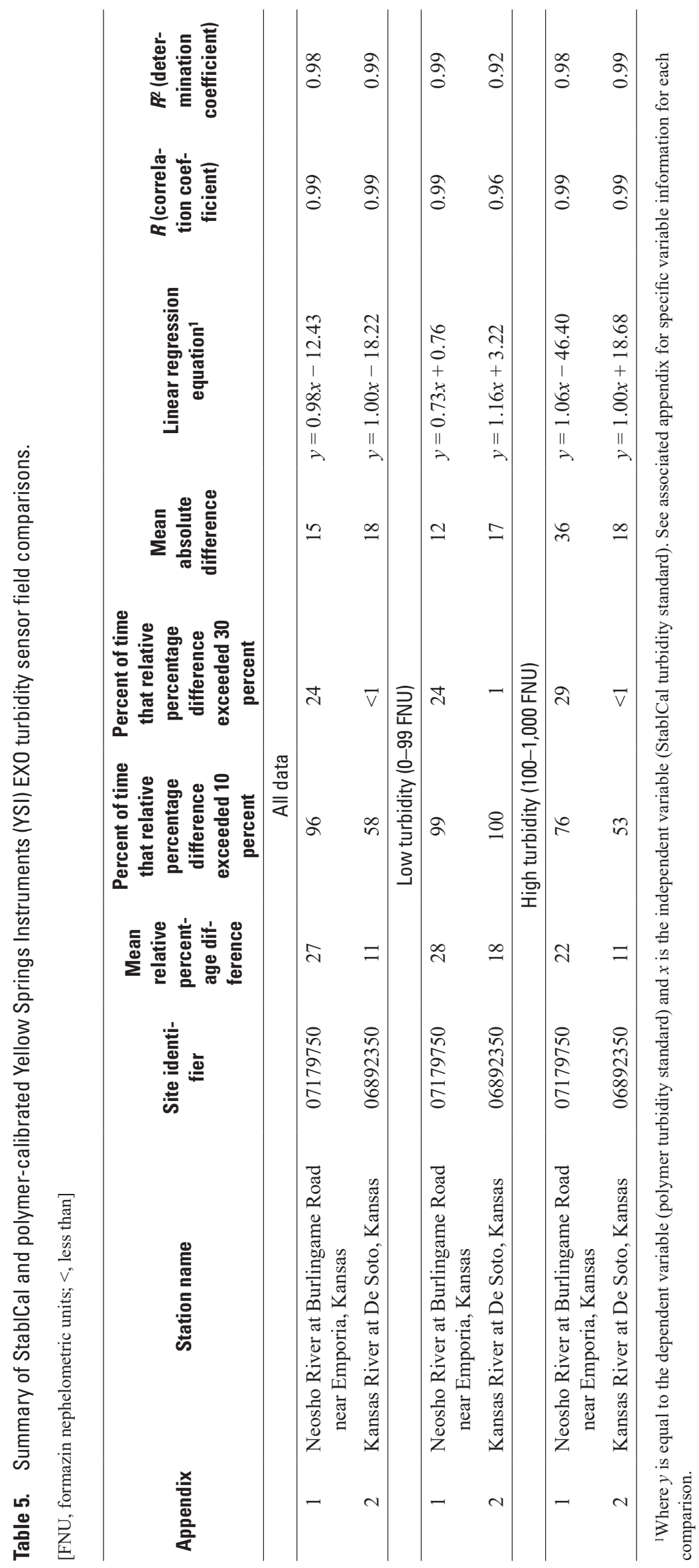


Table 6. Summary of StabICal- and polymer-calibrated Yellow Springs Instruments (YSI) EXO turbidity sensor laboratory comparisons.

[Each test was conducted at the Kansas Water Science Center laboratory, Lawrence, Kansas. --, comparison not conducted]

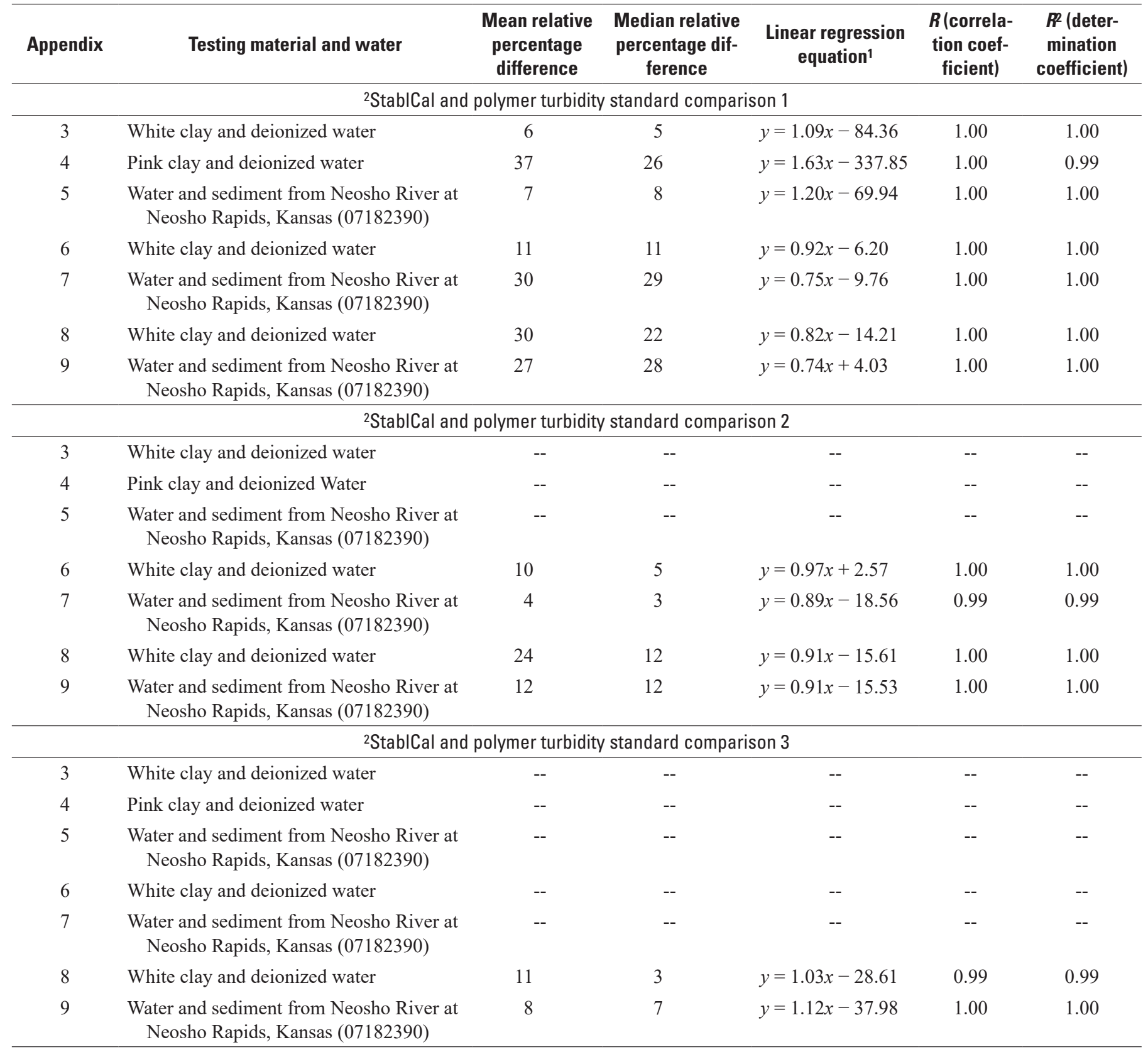

${ }^{1}$ Where $y$ is equal to the dependent variable (polymer turbidity standard) and $x$ is the independent variable (StablCal turbidity standard). See associated appendix for specific variable information for each comparison.

${ }^{2}$ Specific calibration standard lot numbers can be found in the associated appendix for each test 


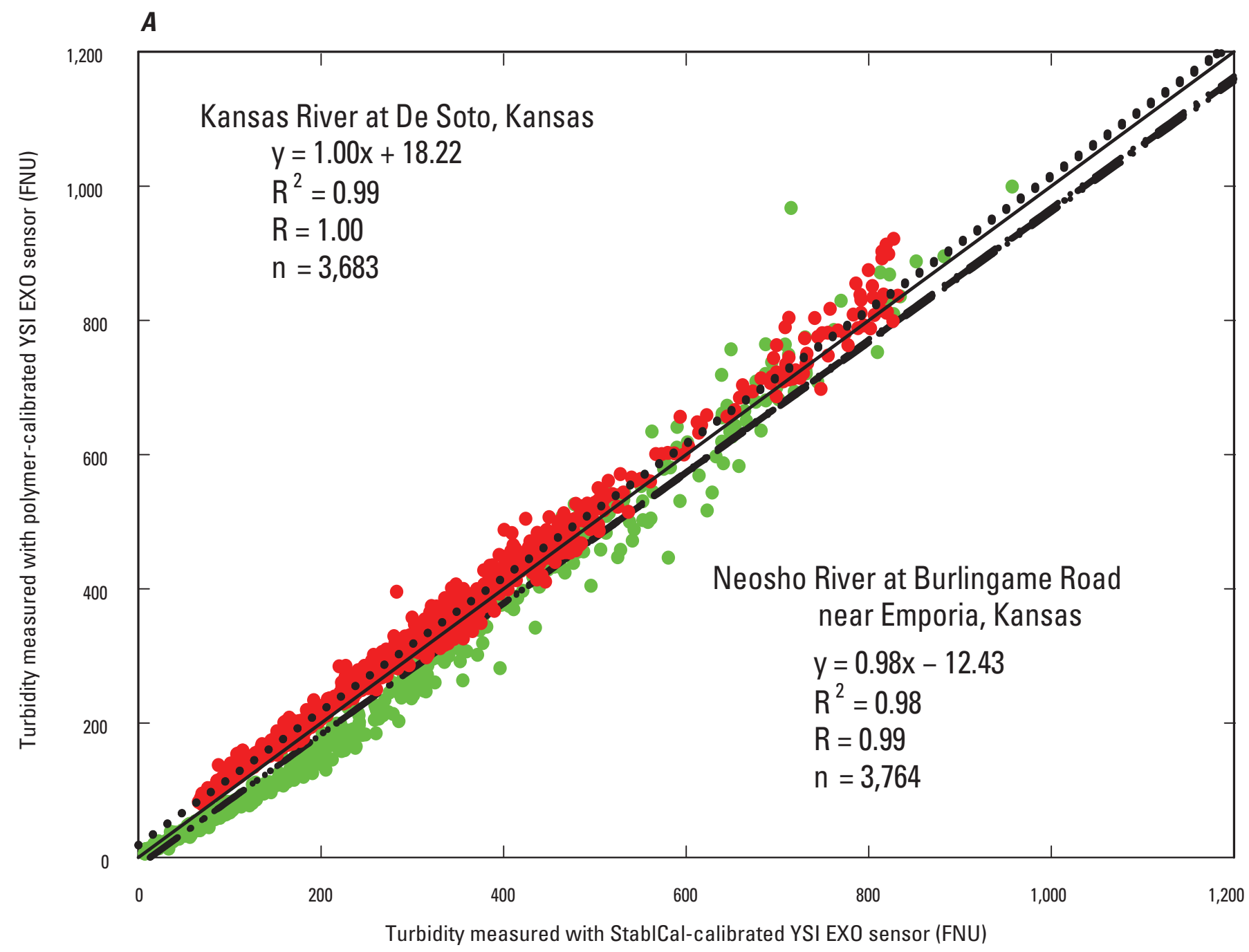

\section{EXPLANATION}

1:1 line

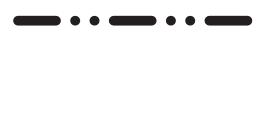
Regression line and 95-percent confidence interval for station at Neosho River at Burlingame Road near Emporia, Kansas

Regression line and 95-percent confidence interval for station at Kansas River at De Soto, Kansas

Turbidity measured at Neosho River at Burlingame Road near Emporia, Kansas

$\bullet$

Turbidity measured at Kansas River at De Soto, Kansas

Figure 8. A, Linear association for all field comparisons of StablCal and polymer turbidity standards; $B$, relative percentage difference (RPD) for all field comparisons for StablCal and polymer turbidity standards; $C$, difference in turbidity for all field comparisons for StabICal and polymer turbidity standards. FNU, formazin nephelometric units; $n$, number of observations; $R$, correlation coefficient; $R^{2}$, coefficient of determination, YSI, Yellow Springs Instruments. 


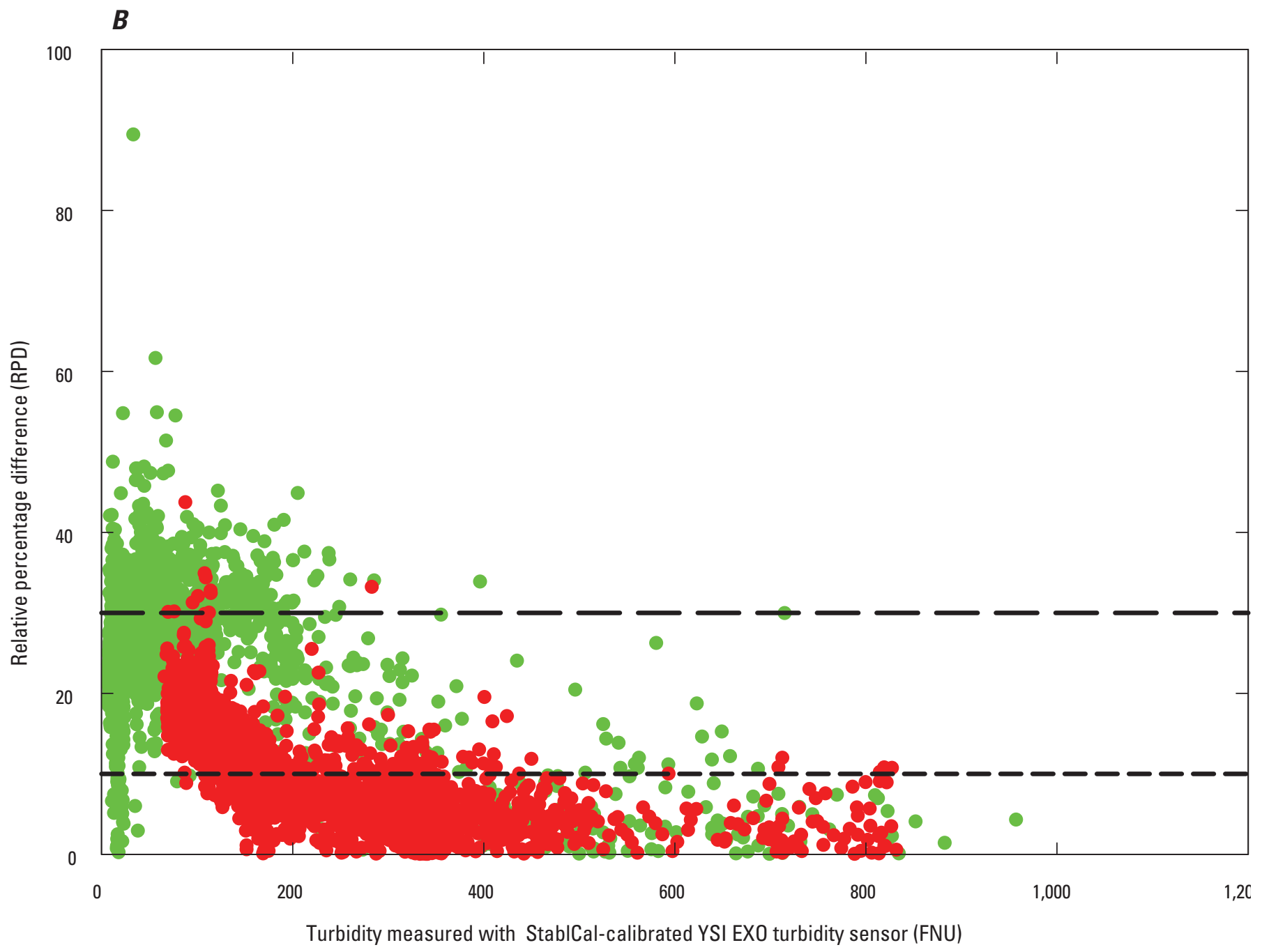

\section{EXPLANATION}

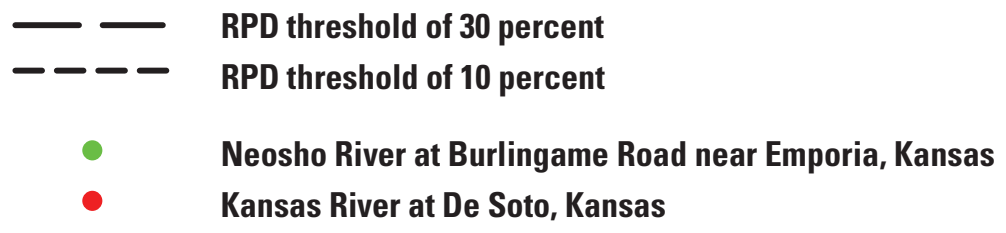

Figure 8.-Continued 


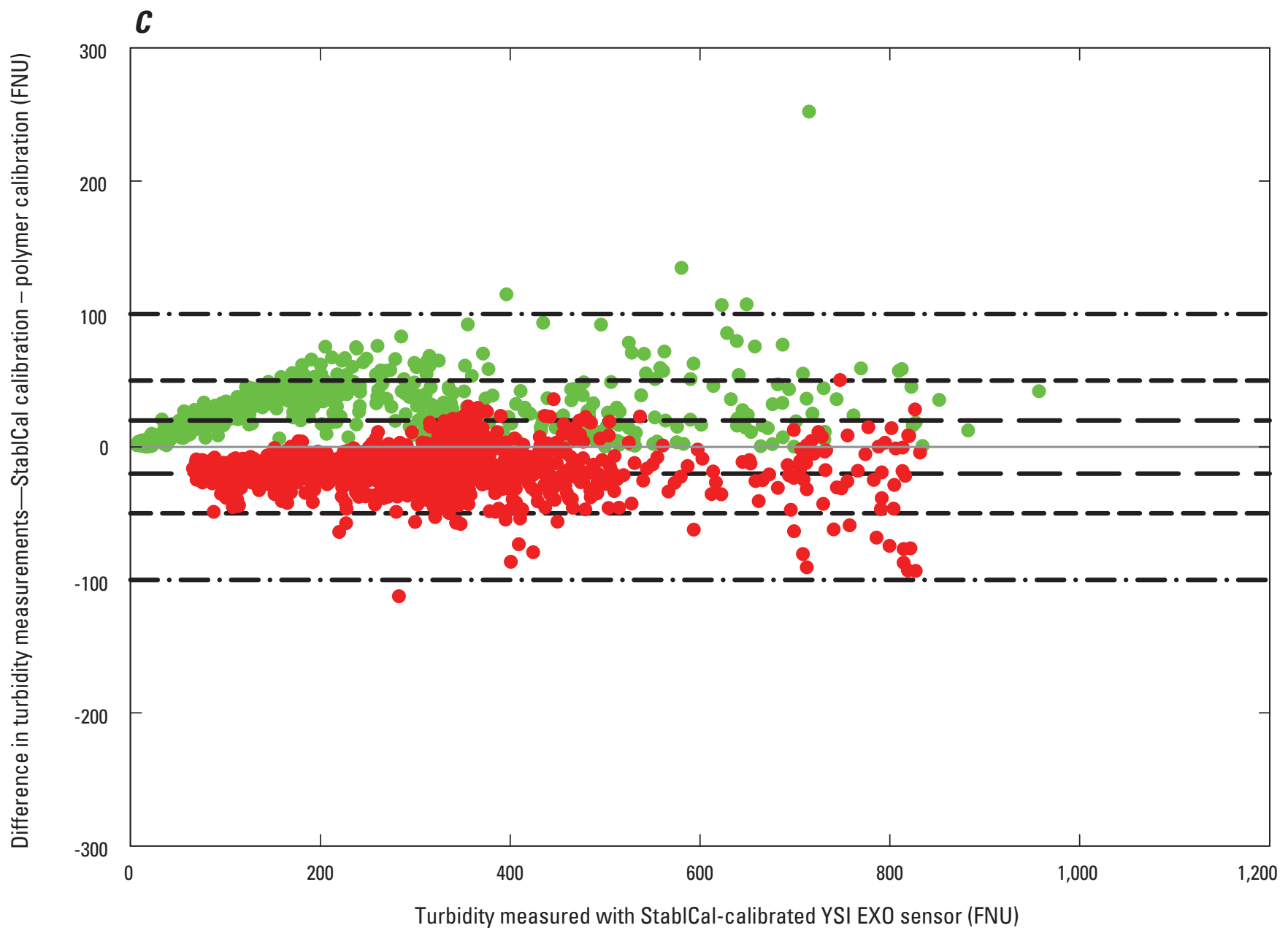

$\begin{array}{ll}- & \text { Line of no difference (0-difference line) } \\ - & \pm 20 \mathrm{FNU} \\ - & \pm 50 \mathrm{FNU} \\ - & \pm 100 \mathrm{FNU} \\ & \text { Neosho River at Burlingame Road near Emporia, Kansas } \\ & \text { Kansas River at De Soto, Kansas }\end{array}$

Figure 8.-Continued 


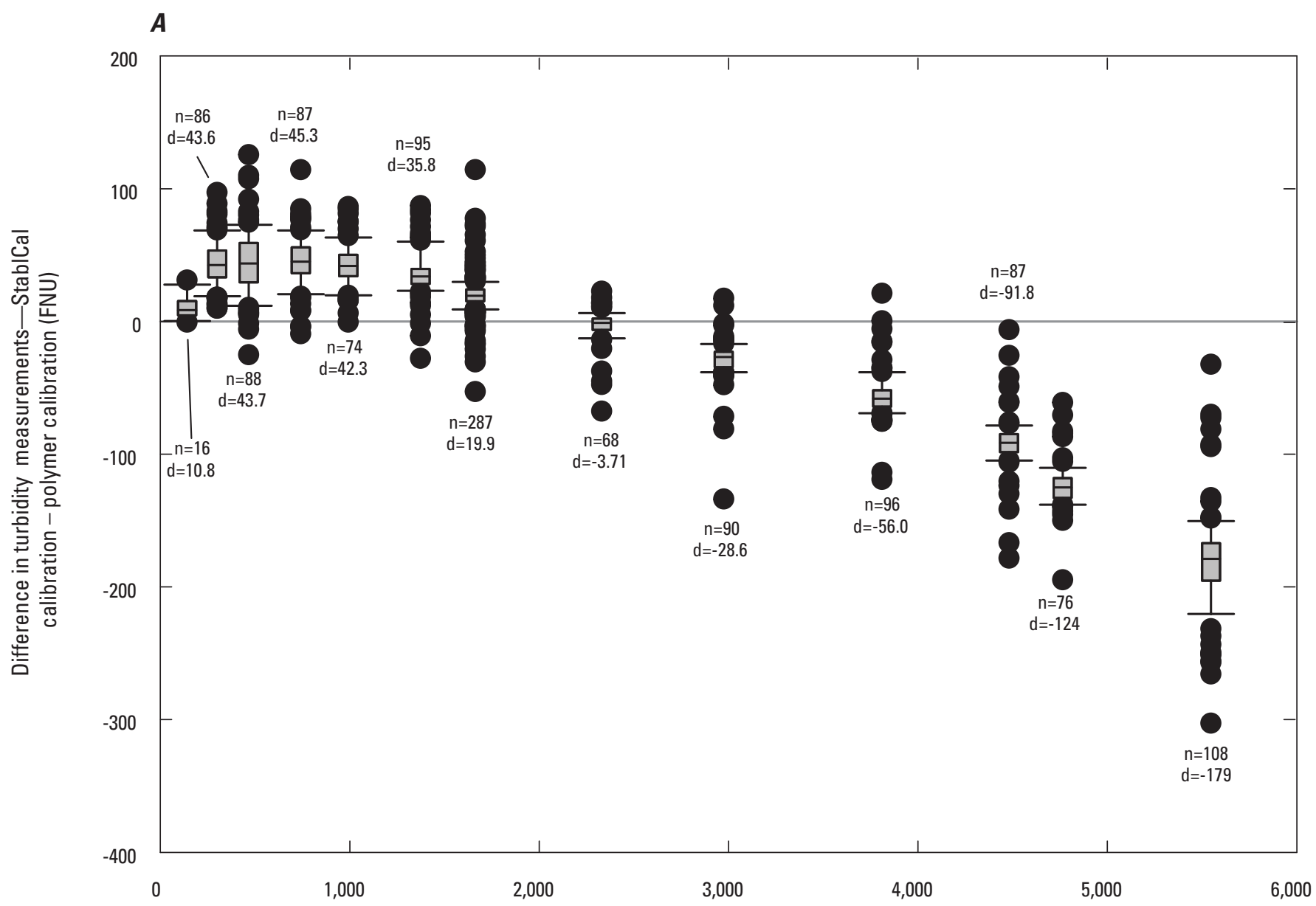

Hach 2100AN turbidity (FNU)

\section{EXPLANATION}

Boxplot

$\left\{\begin{array}{l}\text { 90th percentile } \\ \text { 75th percentile } \\ \text { Median } \\ 25 \text { th percentile } \\ \text { 10th percentile }\end{array}\right.$

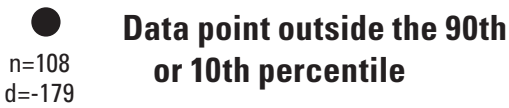

Figure 9. A, Difference in measurements of turbidity in white clay and deionized-water solutions between Yellow Springs Instruments (YSI) EXO turbidity sensors calibrated with StablCal and polymer turbidity standards in relation to Hach 2100AN turbidimeter (app. 3) measurements made at the Kansas Water Science Center laboratory, Lawrence, Kansas; and $B$, difference in measurements of native water and sediment solutions between Yellow Springs Instruments (YSI) EXO turbidity sensors calibrated with StabICal and polymer turbidity standards in relation to the Hach 2100AN turbidimeter-water and sediment solutions collected from the Neosho River at Neosho Rapids, Kansas (U.S. Geological Survey station number 07182390; app. 9) and analyzed at the Kansas Water Science Center laboratory, Lawrence, Kansas. Sensor measurements did not match HACH 2100AN measurements; see appendixes 3 and 9 for additional information. d, average difference in formazin nephelometric units; FNU, formazin nephelometric units; $n$, number of differences between measurements made using sensors calibrated with StablCal and polymer turbidity standards. 


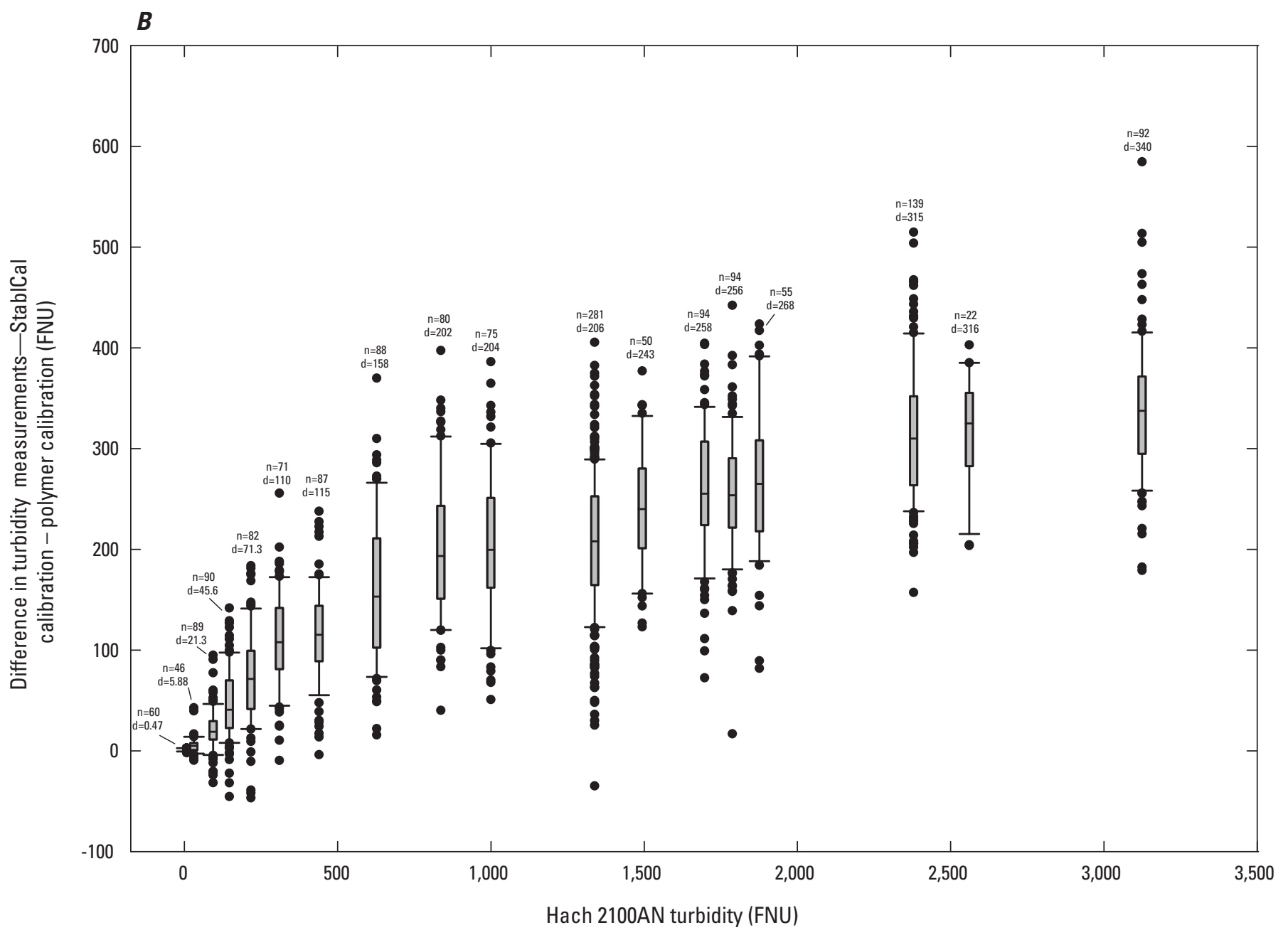

EXPLANATION

\section{Boxplot}

${ }^{90}$ th percentile

75th percentile

Median

25th percentile

$\perp$ 10th percentile

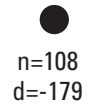

Data point outside the 90th or 10th percentile

Figure 9.-Continued 
The RPD between StablCal- and polymer-calibrated YSI EXO turbidity sensors for all data exceeded the threshold of 10 percent from 58 to 96 percent of the time under field conditions. Turbidity measurements less than 100 FNU had RPDs in exceedance of 10 percent from 99 to 100 percent of the time under field conditions, whereas turbidity measurements equal to or greater than $100 \mathrm{FNU}$ had RPDs greater than 10 percent from 53 to 76 percent of the time (table 5). The 30-percent threshold was rarely exceeded at measurements above 200 FNU under field conditions (fig. $8 B$ ). The range of mean RPDs for comparison of field turbidity measurements less than 100 FNU was 18 to 28 percent; the range of mean RPDs for comparison of field turbidity measurements equal to or greater than $100 \mathrm{FNU}$ was smaller, ranging from 11 to 22 percent (table 5). Absolute differences ranged from 0.04 to $252 \mathrm{FNU}$, but most differences were $100 \mathrm{FNU}$ or less (fig. 8C). Median differences between StableCal- and polymer-calibrated turbidity sensors were statistically significant $(p<0.05)$ under field conditions (app. 1-2).

In the laboratory, mean RPDs between StablCal- and polymer-calibrated turbidity sensors measuring turbidity in native suspended sediment were similar to those observed in the field, ranging from 7 to 39 percent (table 6), despite the fact that laboratory conditions were more controlled. Under laboratory conditions, turbidity readings varied substantially across the range of conditions tested, with differences ranging from near 0 to almost $600 \mathrm{FNU}$ (figs. $9 A, B$ ); the variability is likely caused by the physical challenges inherent in maintaining particles in a uniform suspension. Despite this variability, differences between calibration methods were statistically significant in most laboratory comparisons $(p<0.05)$, even under the controlled laboratory conditions (table 6; app. 3-9).

Results of individual comparison tests between individual turbidity sensors calibrated by using multiple polymer lot numbers are provided in table 7 and appendixes 6 to 9. Patterns in among-lot variability were similar to patterns observed among calibration-standard types (table 7; figs. $10 A, B)$. A strong linear correlation ( $R$ greater than 0.70 ) was found between the different polymer lot numbers for each test conducted, with $R$ values ranging from 0.99 to 1.0 (table 7). Mean RPDs between individual turbidity sensors calibrated by using different polymer lot numbers were all greater than 10 percent and ranged from 15 to 32 percent. Directional differences were observed in turbidity data collected with sensors calibrated by using different polymer lot numbers (figs. 10A, B). Median differences between individual turbidity sensors calibrated by using multiple polymer lot numbers were statistically significant $(p<0.05)$ in all tests (app. 6-9).

Each laboratory test included a comparison measurement from the Hach 2100AN turbidimeter (tables 8, 9; appendixes 3-9). The median RPDs of both StablCal- and polymer-calibrated YSI EXO turbidity sensors were similar to those for the Hach 2100AN, and all were greater than 10 percent (median RPD range, 19-64 percent). All comparisons to the 2100AN were strongly linearly correlated $(R$ greater than 0.70 ) and ranged from 0.89 to 0.99 . 
Table 7. Summary of laboratory comparisons of individual turbidity sensors calibrated by using different lots of polymer standard.

[Each test was conducted at the Kansas Water Science Center laboratory, Lawrence, Kansas. --, comparison not conducted]

\begin{tabular}{|c|c|c|c|c|c|c|}
\hline Appendix & Testing material and water & $\begin{array}{c}\text { Mean relative } \\
\text { percentage } \\
\text { difference }\end{array}$ & $\begin{array}{l}\text { Median rela- } \\
\text { tive percent- } \\
\text { age difference }\end{array}$ & $\begin{array}{l}\text { Linear regression } \\
\text { equation }\end{array}$ & $\begin{array}{c}R \text { (correla- } \\
\text { tion coef- } \\
\text { ficient) }\end{array}$ & $\begin{array}{c}R^{2} \text { (deter- } \\
\text { mination } \\
\text { coefficient) }\end{array}$ \\
\hline \multicolumn{7}{|c|}{ Polymer turbidity standard lot 1 and lot 2 comparison 1,2} \\
\hline 6 & White clay and deionized water & 16 & 8 & $y=1.06 x+9.30$ & 1.00 & 1.00 \\
\hline 7 & $\begin{array}{l}\text { Water and sediment from Neosho River at } \\
\text { Neosho Rapids, Kansas (07182390) }\end{array}$ & 15 & 15 & $y=1.18 x-7.65$ & 1.00 & 1.00 \\
\hline 59 & $\begin{array}{l}\text { Water and sediment from Neosho River at } \\
\text { Neosho Rapids, Kansas (07182390) }\end{array}$ & 15 & 16 & $y=1.22 x-19.51$ & 1.00 & 1.00 \\
\hline \multicolumn{7}{|c|}{ Polymer turbidity standard lot 1 and lot 3 comparison 1,3} \\
\hline 6 & White clay and deionized water & -- & -- & -- & -- & -- \\
\hline 7 & $\begin{array}{l}\text { Water and sediment from Neosho River at } \\
\text { Neosho Rapids, Kansas (07182390) }\end{array}$ & -- & -- & -- & -- & -- \\
\hline \multicolumn{7}{|c|}{ Polymer turbidity standard lot 2 and lot 3 comparison 1,4} \\
\hline 6 & White clay \& deionized water & -- & -- & -- & -- & -- \\
\hline 7 & $\begin{array}{l}\text { Water and sediment from Neosho River at } \\
\text { Neosho Rapids, Kansas (07182390) }\end{array}$ & -- & -- & -- & -- & -- \\
\hline 58 & White clay and deionized water & 17 & 11 & $y=1.14 x-11.12$ & 1.00 & 1.00 \\
\hline 59 & $\begin{array}{c}\text { Water and sediment from Neosho River at } \\
\text { Neosho Rapids, Kansas (07182390) }\end{array}$ & 18 & 19 & $y=1.23 x-18.86$ & 1.00 & 1.00 \\
\hline
\end{tabular}

${ }^{1}$ Specific calibration standard lot numbers can be found in the associated appendix for each test.

${ }^{2}$ Where $y$ is equal to the dependent variable (polymer turbidity standard lot 2), and $x$ is the independent variable (polymer turbidity standard lot 1). See associated appendix for specific variable information for each comparison.

${ }^{3}$ Where $y$ is equal to the dependent variable (polymer turbidity standard lot 3 ), and $x$ is the independent variable (polymer turbidity standard lot 1 ). See associated appendix for specific variable information for each comparison.

${ }^{4}$ Where $y$ is equal to the dependent variable (polymer turbidity standard lot 3 ), and $x$ is the independent variable (polymer turbidity standard lot 2). See associated appendix for specific variable information for each comparison.

${ }^{5}$ For those referenced to appendixes 22 and 23, three Yellow Springs Instruments (YSI) EXO turbidity sensors were run simultaneously on a single YSI EXO body, allowing for three paired comparisons. 


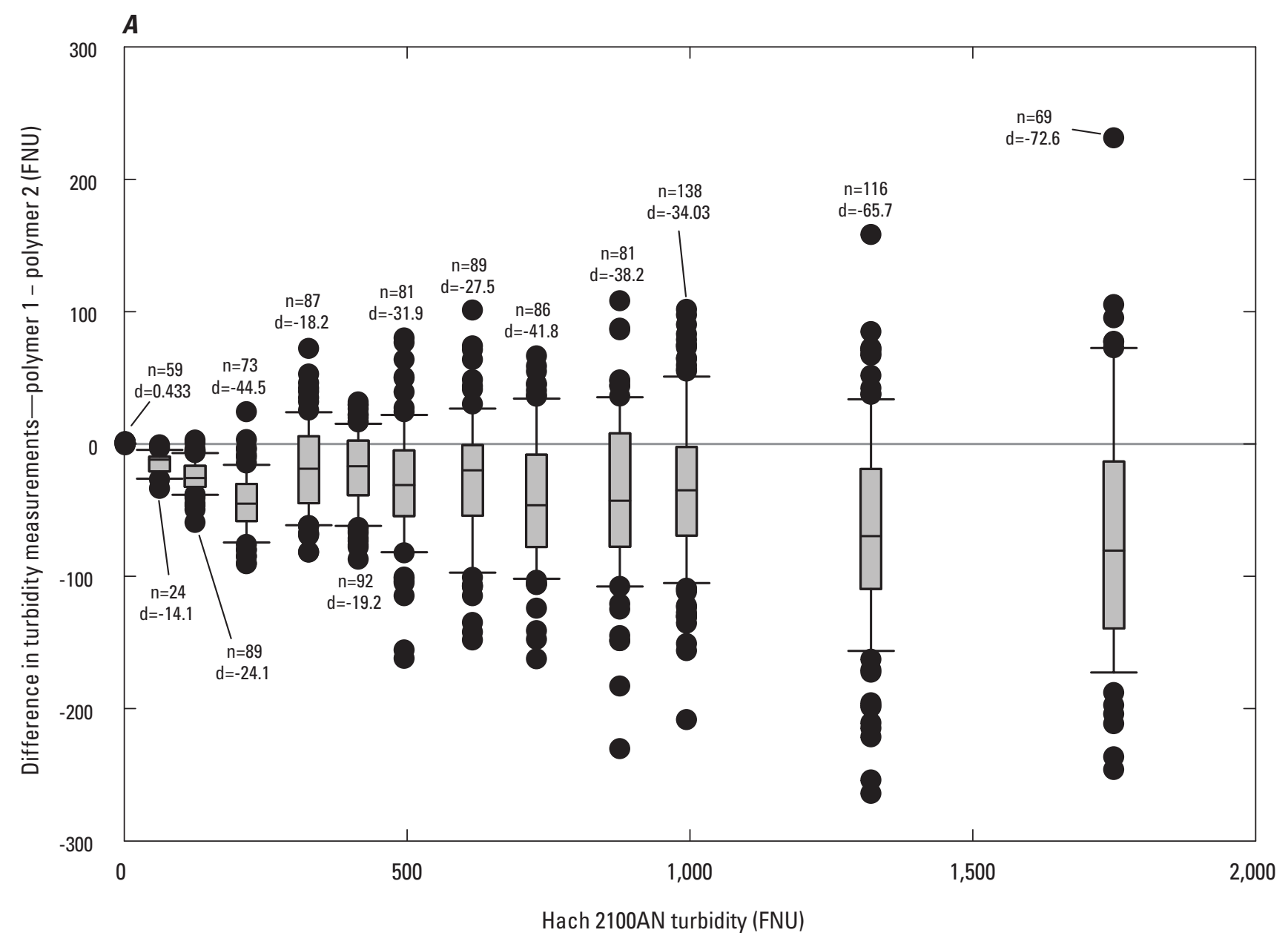

EXPLANATION

\section{Boxplot}

$\left\{\begin{array}{l}\text { 90th percentile } \\ \text { 75th percentile } \\ \text { Median } \\ \text { 25th percentile } \\ \text { 10th percentile }\end{array}\right.$

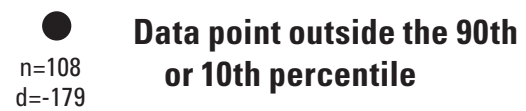

Figure 10. Difference between measurements made with Yellow Springs Instruments (YSI) EXO turbidity sensors calibrated with two different lot numbers of polymer turbidity standards in relation to Hach 2100AN turbidimeter, for comparisons with $A$, a white clay and deionized-water solution (app. 6); and B, a solution of sediment and water from the Neosho River at Neosho Rapids, Kansas (U.S. Geological Survey station number 07182390; app. 7)—samples analyzed at the Kansas Water Science Center laboratory, Lawrence, Kansas. Sensor measurements did not match HACH 2100AN measurements; see appendixes 6 and 7 for additional information. $d$, average difference in formazin nephelometric units; FNU, formazin nephelometric units; $n$, number of differences between measurements made using sensors calibrated with StabICal and polymer turbidity standards. 


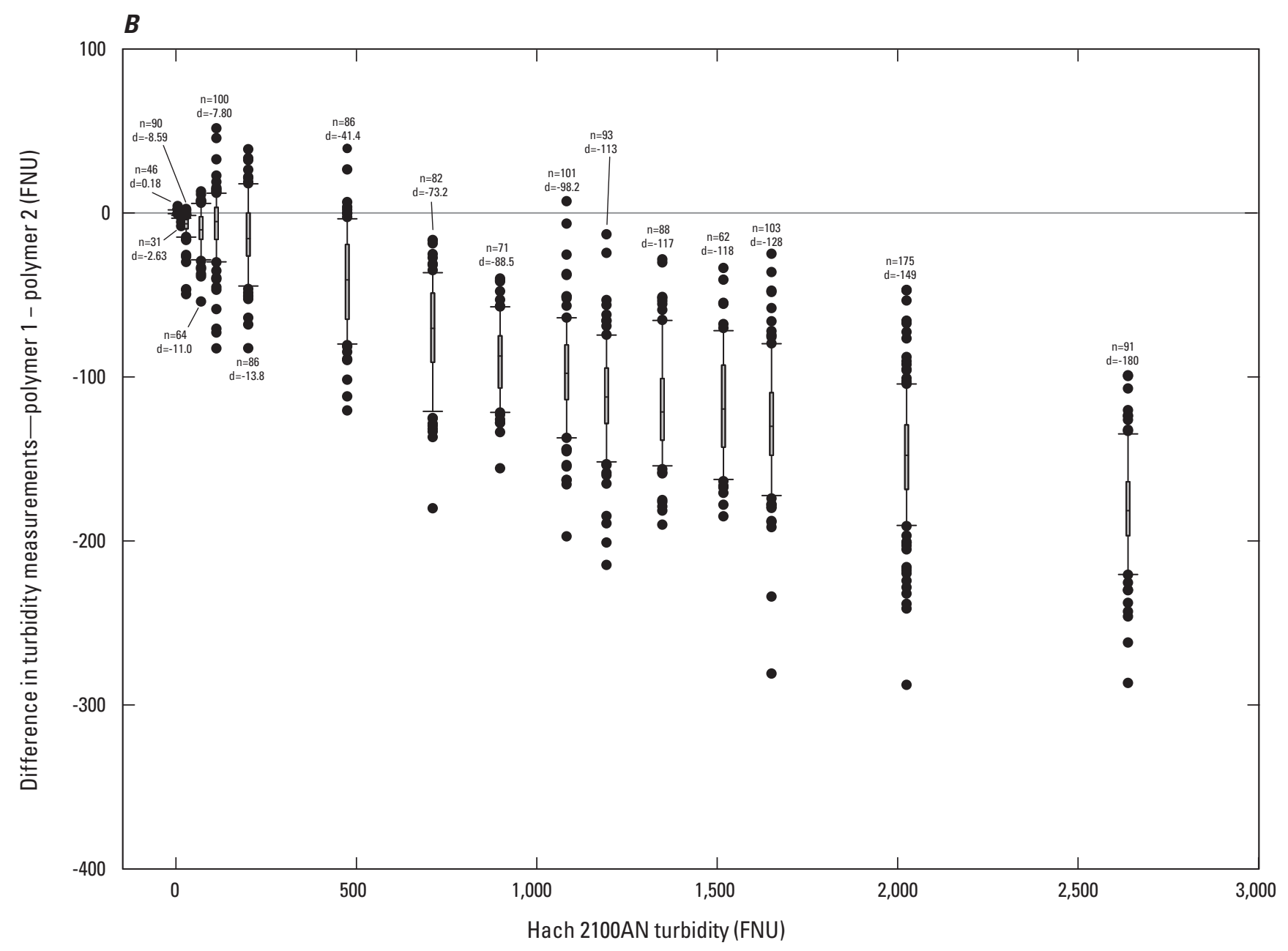

EXPLANATION

\section{Boxplot}

$\left\{\begin{array}{l}\text { 90th percentile } \\ \text { 75th percentile } \\ \text { Median } \\ \text { 25th percentile } \\ \text { 10th percentile }\end{array}\right.$

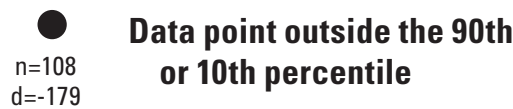

Figure 10.-Continued 
Table 8. Summary of comparisons between the Hach 2100AN turbidimeter and Yellow Springs Instruments EXO turbidity sensors calibrated by using different lots of StableCal standard.

[Each test was conducted at the Kansas Water Science Center laboratory, Lawrence, Kansas]

\begin{tabular}{|c|c|c|c|c|c|c|}
\hline \multirow[b]{2}{*}{ Appendix } & \multirow[b]{2}{*}{ Testing material and water } & \multicolumn{5}{|c|}{ StabICal-calibrated EXO turbidity sensor and Hach 2100AN turbidimeter comparison ${ }^{1}$} \\
\hline & & $\begin{array}{c}\text { Mean relative } \\
\text { percentage } \\
\text { difference }\end{array}$ & $\begin{array}{l}\text { Median rela- } \\
\text { tive percentage } \\
\text { difference }\end{array}$ & $\begin{array}{l}\text { Linear regression } \\
\text { equation }^{2}\end{array}$ & $\begin{array}{c}R \text { (correla- } \\
\text { tion coef- } \\
\text { ficient) }\end{array}$ & $\begin{array}{c}\boldsymbol{R}^{2} \text { (deter- } \\
\text { mination } \\
\text { coefficient) }\end{array}$ \\
\hline 3 & White clay and deionized water & 45 & 52 & $y=0.43 x+212.31$ & 1.00 & 0.99 \\
\hline 4 & Pink clay and deionized Water & 35 & 33 & $y=0.42 x+236.27$ & 0.99 & 0.99 \\
\hline 8 & $\begin{array}{l}\text { Water and sediment from Neosho River } \\
\text { at Neosho Rapids, Kansas (07182390) }\end{array}$ & 46 & 28 & $y=0.20 x+440.74$ & 0.89 & 0.79 \\
\hline 6 & White clay and deionized water & 29 & 30 & $y=0.58 x+76.65$ & 0.98 & 0.96 \\
\hline 7 & $\begin{array}{l}\text { Water and sediment from Neosho River } \\
\text { at Neosho Rapids, Kansas (07182390) }\end{array}$ & 36 & 33 & $y=0.50 x+159.10$ & 0.94 & 0.89 \\
\hline 8 & White clay and deionized water & 47 & 45 & $y=0.49 x+164.66$ & 0.99 & 0.98 \\
\hline 9 & $\begin{array}{l}\text { Water and sediment from Neosho River } \\
\text { at Neosho Rapids, Kansas (07182390) }\end{array}$ & 35 & 29 & $y=0.42 x+224.60$ & 0.94 & 0.89 \\
\hline
\end{tabular}

${ }^{1}$ Specific calibration standard lot numbers can be found in the associated appendix for each test.

${ }^{2}$ Where $y$ is equal to the dependent variable (StablCal-calibrated EXO sensor), and $x$ is the independent variable (Hach 2100 AN turbidimeter). See associated appendix for specific variable information for each comparison. 
Table 9. Summary of comparisons between the Hach 2100AN turbidimeter and Yellow Springs Instruments EXO turbidity sensors calibrated by using different lots of polymer standard.

[Each test was conducted at the Kansas Water Science Center laboratory, Lawrence, Kansas. --, comparison not conducted]

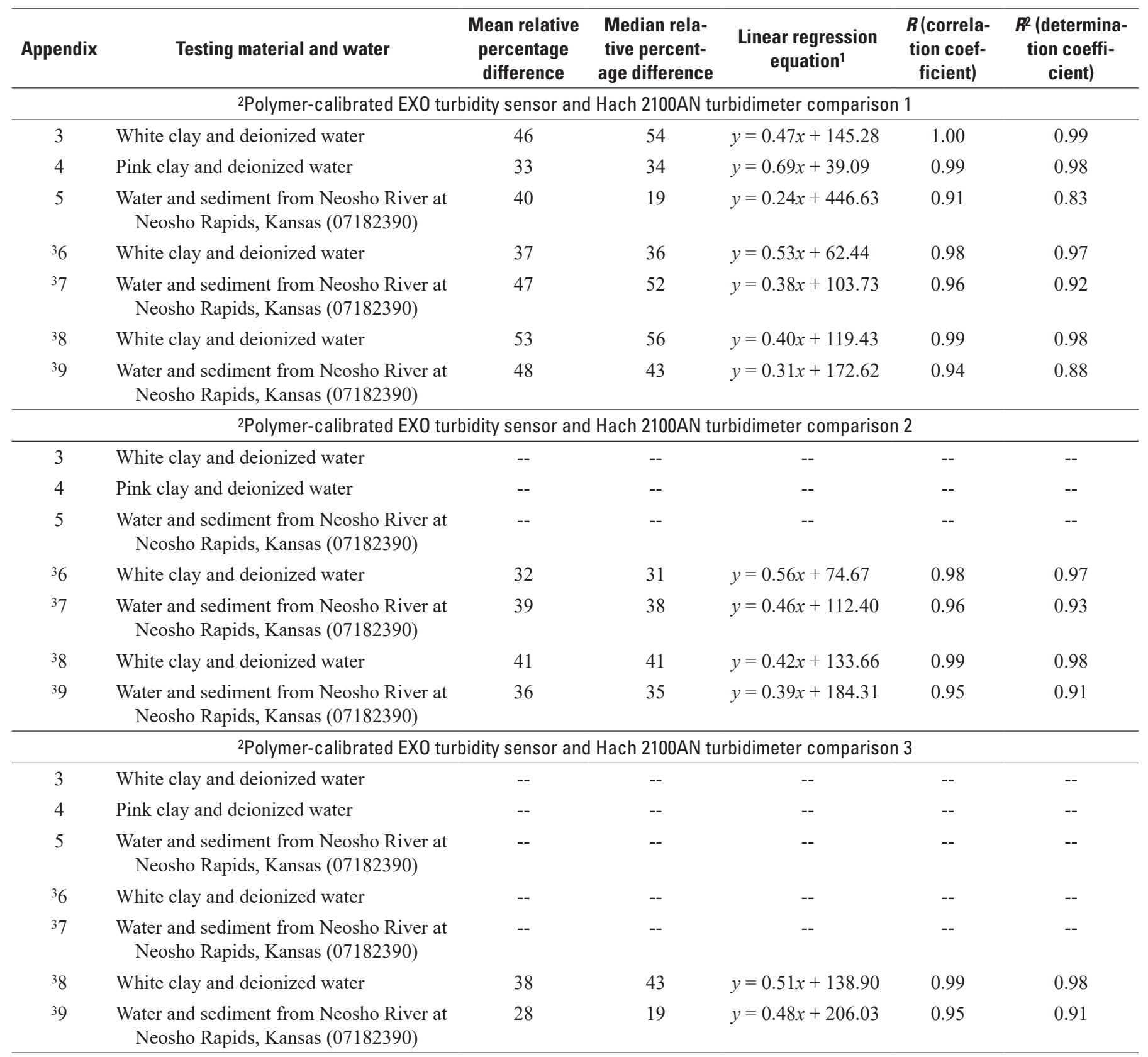

${ }^{1}$ Where $y$ is equal to the dependent variable (polymer-calibrated EXO sensor), and $x$ is the independent variable (Hach 2100AN turbidimeter). See associated appendix for specific variable information for each comparison.

${ }^{2}$ Specific calibration standard lot numbers can be found in the associated appendix for each test.

${ }^{3}$ For those referenced to appendixes 20 through 23, multiple Yellow Springs Instruments (YSI) EXO turbidity sensors were run simultaneously on a single YSI EXO body, allowing for multiple paired comparisons. 


\section{Results of Sensor Comparison Tests}

Results of field comparison tests between YSI EXO and YSI 6136 turbidity sensors are provided in table 10 and appendixes 10 to 18. Results of laboratory comparison tests between YSI EXO and YSI 6136 turbidity sensors are provided in table 11 and appendixes 19 to 23 . Table 11 also includes pairwise comparisons of the two YSI sensor types against the Hach 2100AN sensor. A strong linear correlation $(R$ greater than 0.70) was found between the YSI EXO and YSI 6136 turbidity sensors in all tests in both field and laboratory conditions (tables 10, 11; fig. 11A). However, linear associations (slopes) were not necessarily 1:1 and varied by comparison. A consistent bias was not observed, but either associations were near 1:1 or turbidity measurements for the YSI 6136 (dependent variable) were higher than those made with the YSI EXO (independent variable; slopes ranged from 0.98 to 1.40), excluding one field comparison (slope of 0.50 ) and a comparison made with black clay (slope 0.87 ). One $100-1,000$-FNU (high-turbidity conditions) dataset was excluded because the sample size was small ( $n=22$; app. 12, table 10$)$; results for black clay were excluded from "all data" comparisons because light-absorption effects consistently caused these data to be outliers.

Under field conditions, the RPD between measurements made with YSI EXO and YSI 6136 turbidity sensors for all data exceeded the threshold of 10 percent 74 percent of the time, and the RPD of 30 percent was exceeded 37 percent of the time (fig. 11B). At individual sites, mean RPDs exceeded the 10-percent threshold and ranged from 10 to 82 percent (table 10). RPDs were higher when turbidity was less than 100 FNU (mean range 10-83 percent) than when turbidity was greater than $100 \mathrm{FNU}$ (mean range 9-37 percent) (table 10, fig. 11B). Absolute differences between measurements made with YSI EXO and YSI 6136 turbidity sensors ranged from 0 to $420 \mathrm{FNU}$; however, differences were less than $20 \mathrm{FNU}$ for 94 percent of all comparisons (fig. 11C). When turbidity was less than $100 \mathrm{FNU}$, differences were less than $10 \mathrm{FNU}$ for 95 percent of all comparisons (fig. 11C). Therefore, although
RPDs typically exceeded the 10- and 30-percent thresholds, absolute differences between YSI EXO and YSI 6136 turbidity measurements were small. Median differences between YSI EXO and YSI 6136 turbidity sensors were statistically significant $(p<0.05)$ in both laboratory and field conditions (app. 10-18, 19-23).

In the laboratory, the range of mean RPDs between YSI EXO and YSI 6136 turbidity sensors was smaller than that observed in the field, ranging from 14 to 30 percent (table 11). Despite the fact that conditions in the laboratory are controlled, mean RPDs for all laboratory comparisons were greater than 10 percent. Mean RPDs for all laboratory comparisons except one were less than 30 percent. With the exception of comparisons made using black clay, laboratory conditions did not result in substantial changes in the slope of the relation. The difference between the turbidity readings made with the YSI 6136 and YSI EXO turbidity sensors varied substantially across the range of conditions tested (fig. 12). For example, the difference between turbidity readings at a given turbidity value referenced to the HACH 2100AN turbidimeter could range from 0 to more than 400 FNU (fig. 13). Despite this variability, differences in mean turbidity measured with the YSI 6136 and YSI EXO turbidity sensors at a given turbidity value referenced to the HACH 2100AN turbidimeter were statistically significant in all laboratory comparisons (all $p<0.05$ ).

Each laboratory test included a comparison reading from the Hach 2100AN turbidimeter (table 11). The average median RPD for the YSI 6136 turbidity sensors was closer to that for the 2100AN (31 percent) than that for the YSI EXO (41 percent), although both readings were lower than those for the 2100AN. However, when the results for black clay were removed because of the light-absorption effects that caused these data to be outliers, the YSI 6136 and YSI EXO median RPDs decreased to 16 and 32 percent, respectively. All comparisons to the $2100 \mathrm{AN}$ were strongly linearly correlated ( $R$ greater than 0.70 ) except in the black clay experiments, for which the linear correlations were moderate ( $R$ greater than $0.50)$ and weak ( $R$ greater than 0.30 ) for the YSI 6136 and YSI EXO, respectively. 


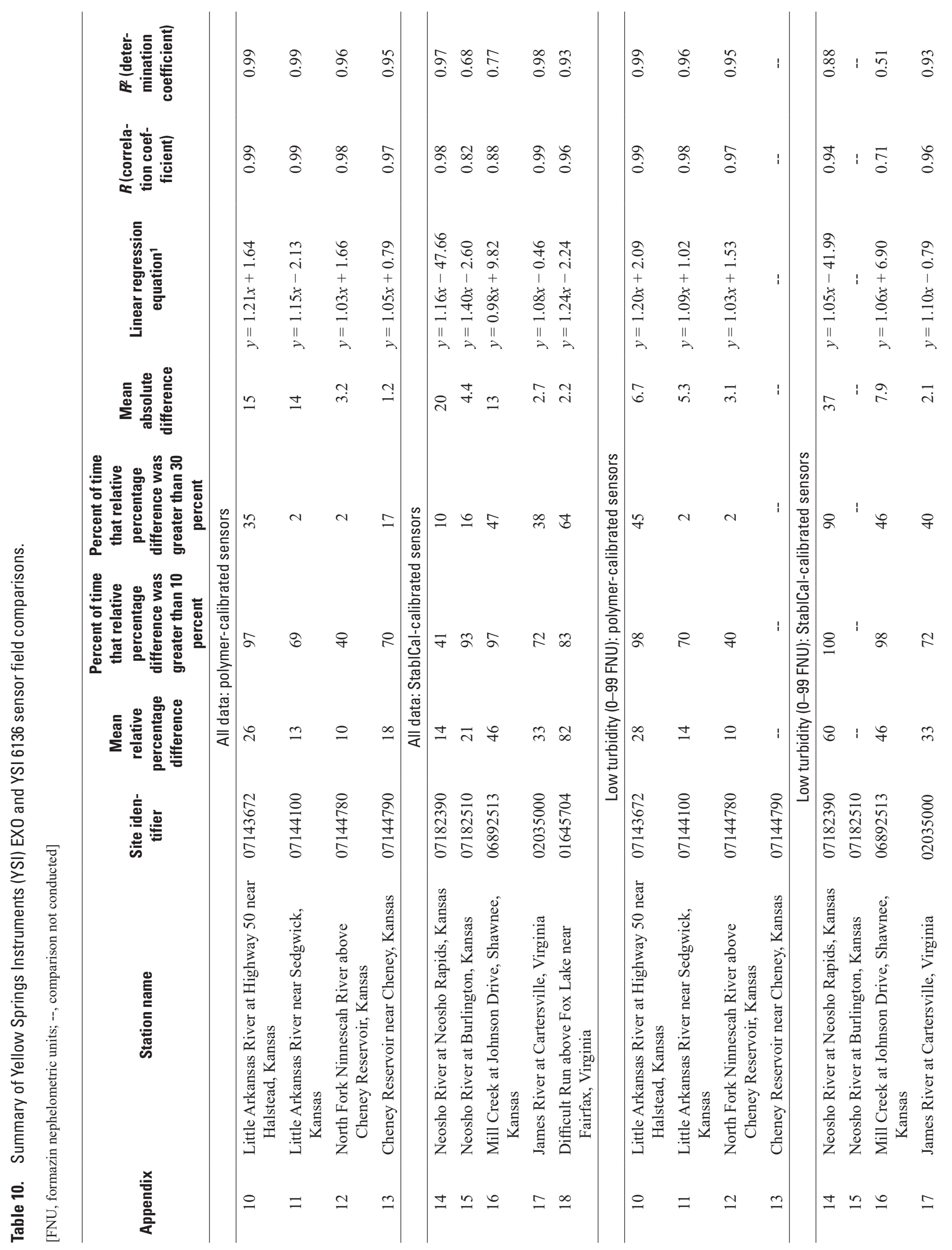




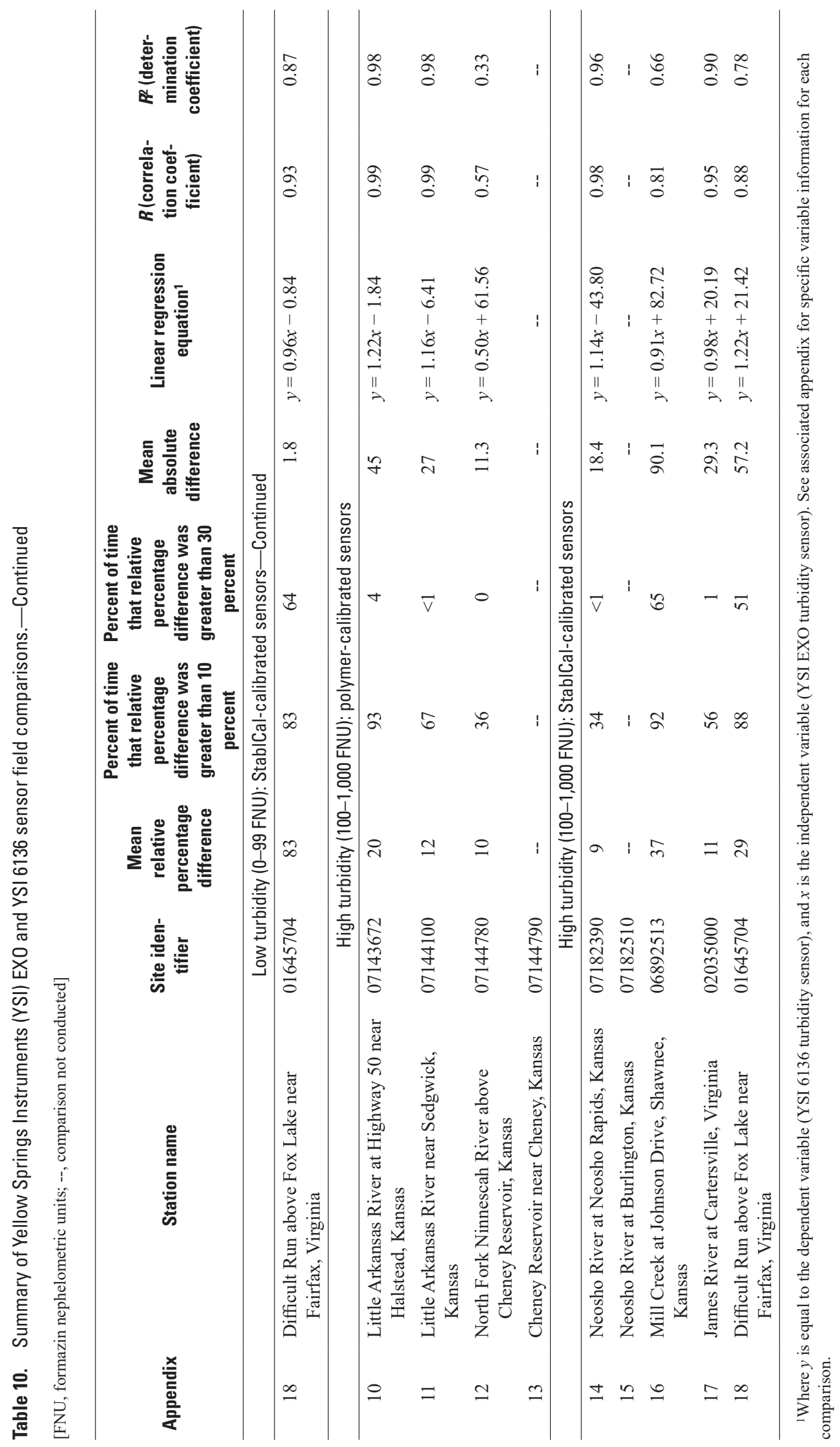


Table 11. Summary of Yellow Springs Instruments (YSI) EXO turbidity sensor, YSI 6136 turbidity sensor, and Hach 2100AN turbidimeter laboratory comparisons.

[Each test was conducted at the Kansas Water Science Center laboratory, Lawrence, Kansas]

\begin{tabular}{|c|c|c|c|c|c|c|}
\hline Appendix & Testing material and water & $\begin{array}{l}\text { Mean relative } \\
\text { percentage } \\
\text { difference }\end{array}$ & $\begin{array}{l}\text { Median rela- } \\
\text { tive percentage } \\
\text { difference }\end{array}$ & $\begin{array}{l}\text { Linear regression } \\
\text { equation }\end{array}$ & $\begin{array}{l}R \text { (correlation } \\
\text { coefficient) }\end{array}$ & $\begin{array}{l}R^{2} \text { (determina- } \\
\text { tion coefficient) }\end{array}$ \\
\hline \multicolumn{7}{|c|}{ EX0 and 6136 turbidity sensors ${ }^{1}$} \\
\hline 19 & White clay and deionized water & 15 & 13 & $y=1.26 x-39.68$ & 1.00 & 1.00 \\
\hline 20 & Black clay and deionized water & 14 & 15 & $y=0.87 x-0.34$ & 0.99 & 0.99 \\
\hline 23 & $\begin{array}{l}\text { Water and sediment from Kansas } \\
\text { River at Wamego, Kansas } \\
(06887500)\end{array}$ & 14 & 15 & $y=1.22 x-19.45$ & 1.00 & 1.00 \\
\hline 21 & Pink clay and deionized water & 37 & 37 & $y=0.50 x+110.91$ & 0.99 & 0.98 \\
\hline 22 & $\begin{array}{l}\text { Water and sediment from Mill } \\
\text { Creek at Johnson Drive, } \\
\text { Shawnee, Kansas (06892513) }\end{array}$ & 42 & 40 & $y=0.63 x+3.92$ & 0.98 & 0.97 \\
\hline 23 & $\begin{array}{l}\text { Water and sediment from Kansas } \\
\text { River at Wamego, Kansas } \\
(06887500)\end{array}$ & 32 & 28 & $y=0.61 x+59.79$ & 0.98 & 0.97 \\
\hline \multicolumn{7}{|c|}{6136 turbidity sensor and Hach 2100AN turbidimeter ${ }^{3}$} \\
\hline 19 & White clay and deionized water & 14 & 13 & $y=0.68 x+113.57$ & 0.99 & 0.98 \\
\hline 20 & Black clay and deionized water & 90 & 89 & $y=-0.03 x+80.22$ & 0.52 & 0.27 \\
\hline
\end{tabular}

${ }^{1}$ Where $y$ is equal to the dependent variable (YSI 6136 turbidity sensor), and $x$ is the independent variable (YSI EXO turbidity sensor). See associated appendix for specific variable information for each comparison.

${ }^{2}$ Where $y$ is equal to the dependent variable (YSI EXO turbidity sensor), and $x$ is the independent variable (Hach 2100AN turbidimeter). See associated appendix for specific variable information for each comparison.

${ }^{3}$ Where $y$ is equal to the dependent variable (YSI 6136 turbidity sensor), and $x$ is the independent variable (Hach 2100AN turbidimeter). See associated appendix for specific variable information for each comparison. 


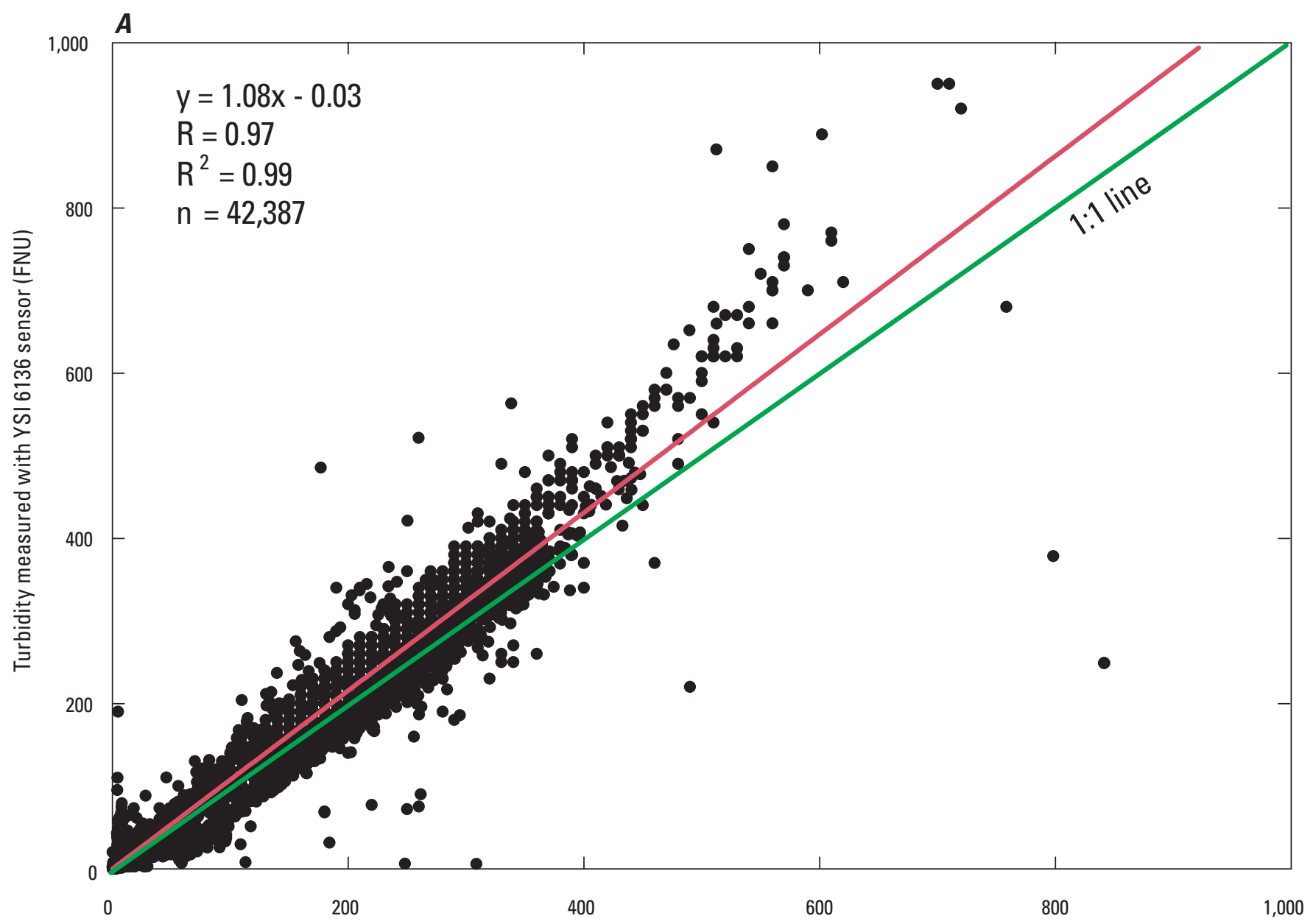

Turbidity measured with YSI EXO sensor (FNU)

Figure 11. $A$, Linear association for all field comparisons of Yellow Springs Instruments (YSI) EXO and YSI 6136 turbidity sensors; $B$, relative percentage difference (RPD) for all field comparisons for YSI EXO and YSI 6136 turbidity sensors; and $C$, difference in turbidity for all field comparisons for YSI EXO and YSI 6136 turbidity sensors. FNU, formazin nephelometric units; n, number of observations; $R$, correlation coefficient; $\mathrm{R}^{2}$, coefficient of determination. 


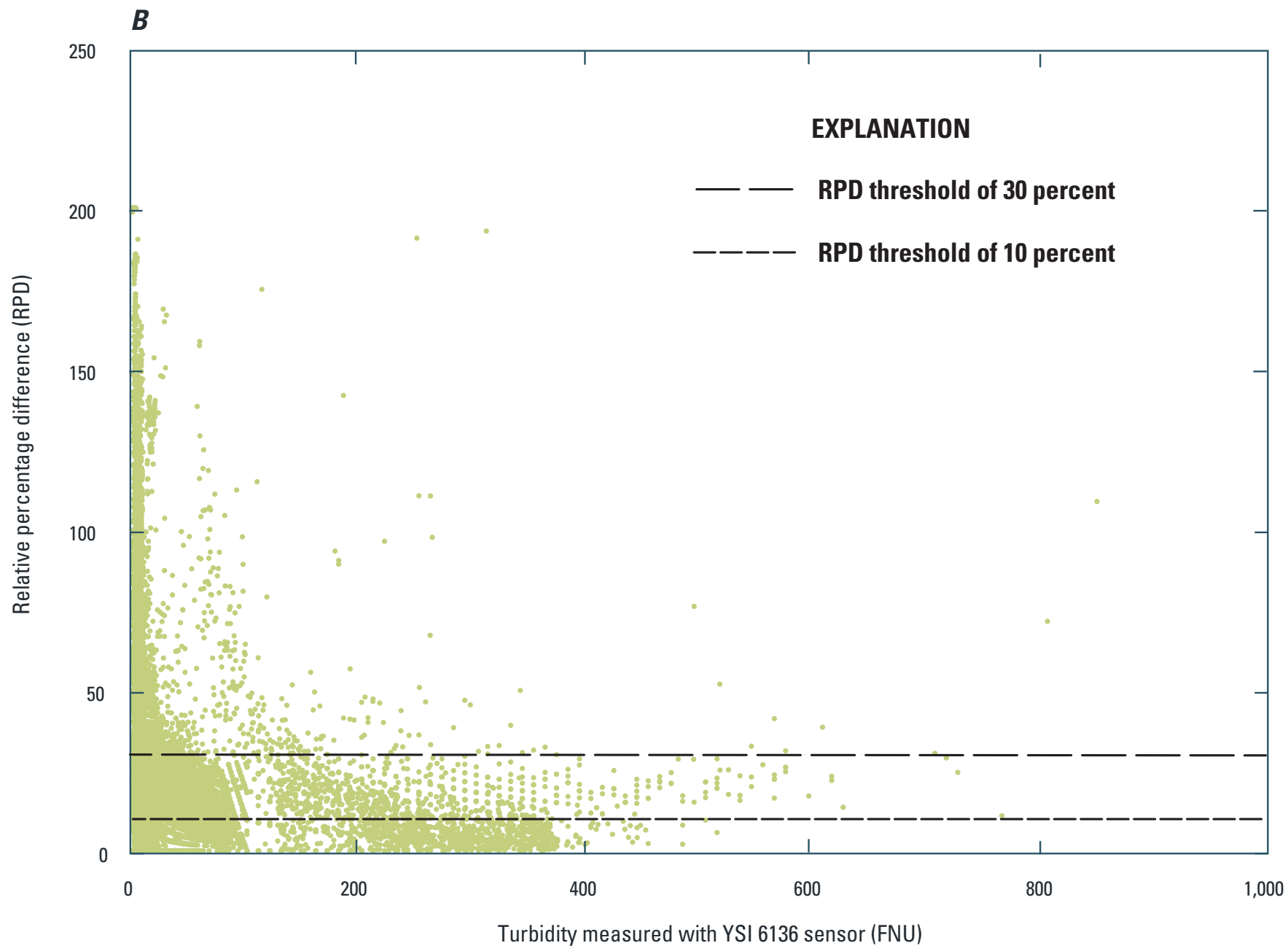

Figure 11.-Continued 


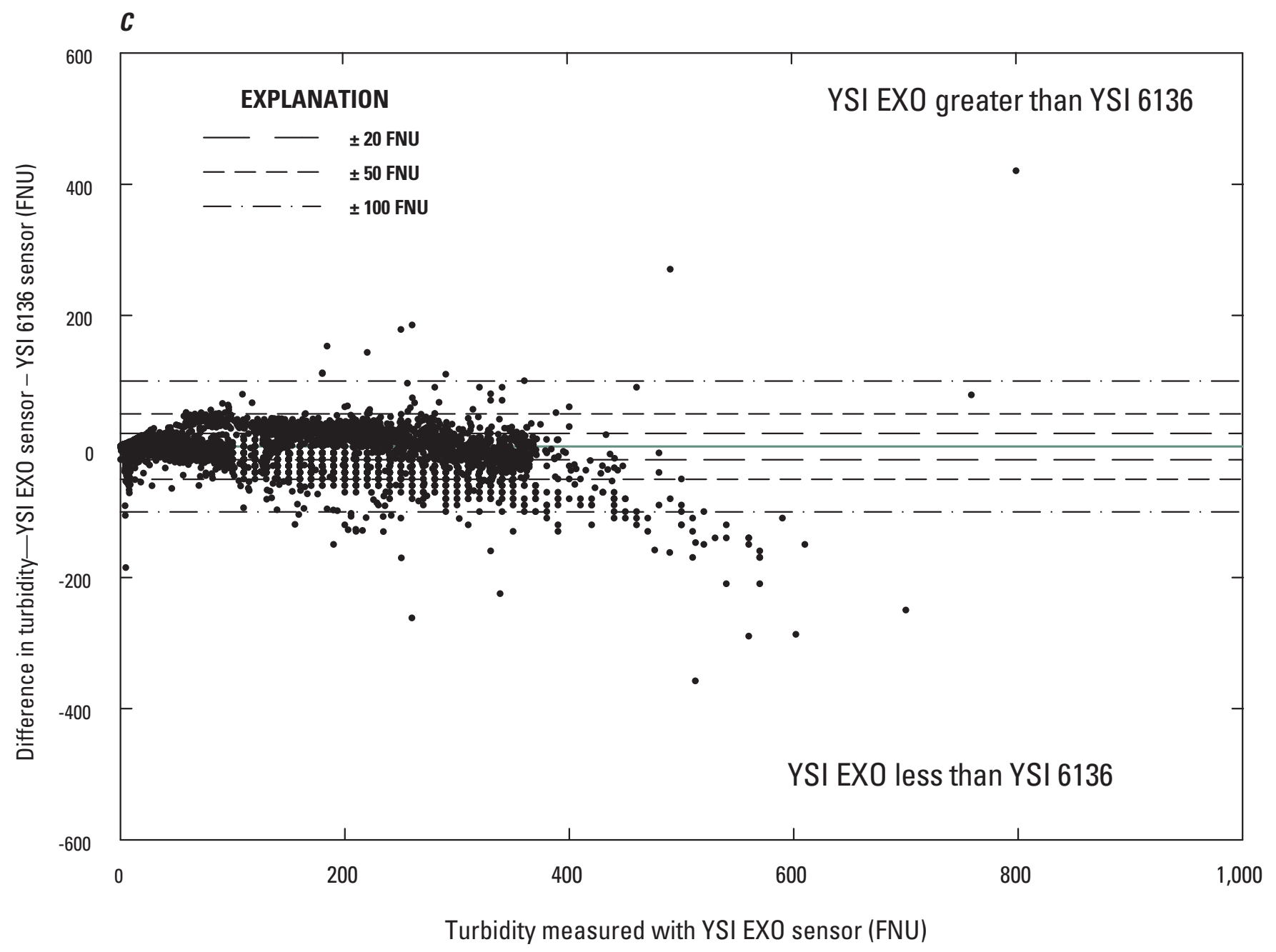

Figure 11.-Continued 


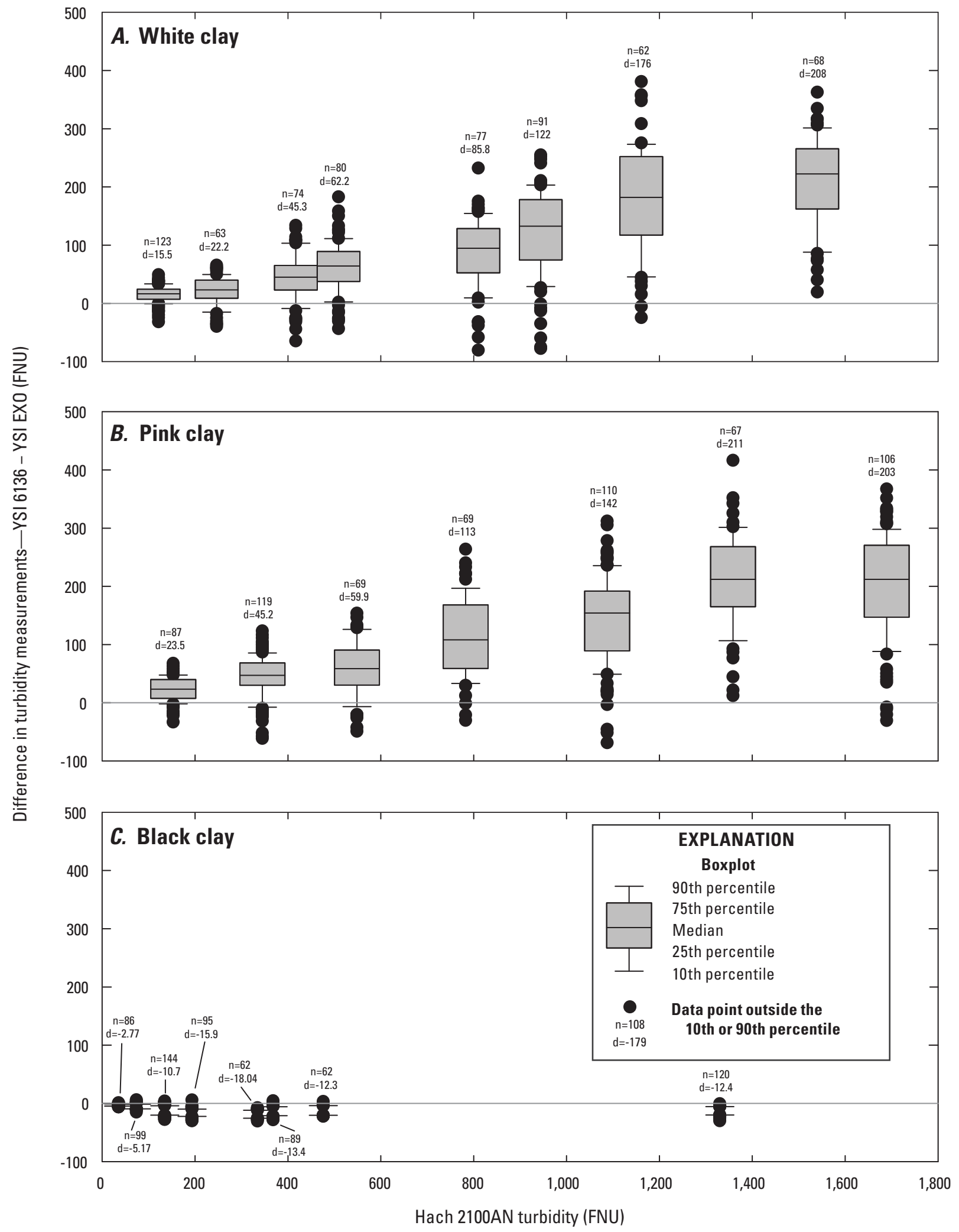

Figure 12. Difference between Yellow Springs Instruments (YSI) 6136 and YSI EXO turbidity measurements in relation to the Hach 2100AN turbidimeter for measurements made in $A$, white clay and deionized-water solution (app. 19); $B$, pink clay and deionized-water solution (app. 21); and $C$, black clay and deionized-water solution (app. 20) at the Kansas Water Science Center laboratory, Lawrence, Kansas. $d$, average difference in formazin nephelometric units; FNU, formazin nephelometric units, n, number of differences between turbidity measured with YSI 6136 and YSI EXO sensors. 


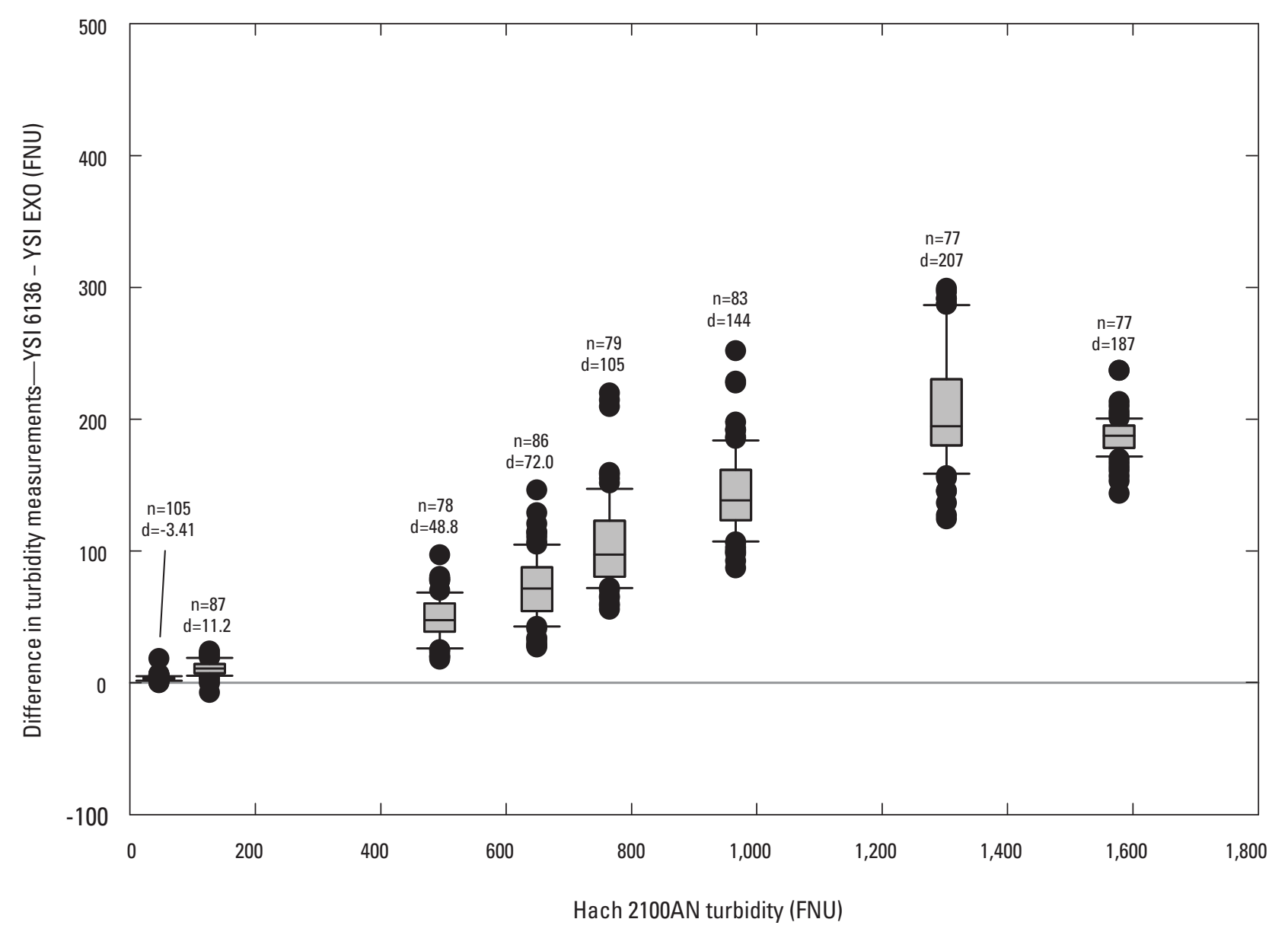

EXPLANATION

\section{Boxplot}

$\left\{\begin{array}{l}\text { 90th percentile } \\ \text { 75th percentile } \\ \text { Median } \\ \text { 25th percentile } \\ \text { 10th percentile }\end{array}\right.$

$\substack{n=108 \\ d=-179}$
Data point outside the 90 th

Figure 13. Difference between Yellow Springs Instruments (YSI) 6136 and YSI EXO turbidity measurements in relation to the Hach 2100AN turbidimeter for measurements made in a solution of sediment and water from the Kansas River at Wamego, Kansas (U.S. Geological Survey station number 06887500, app. 23) and analyzed at the Kansas Water Science Center laboratory, Lawrence, Kansas. Sensor readings did not match those made with the Hach 2100AN sensor; see appendix 23 for additional information. $d$, average difference in formazin nephelometric units; FNU, formazin nephelometric units, n, number of differences between turbidity measured with YSI 6136 and YSI EXO sensors. 


\section{Relative Variability of Selected Turbidity Standards and Sensors}

Regardless of the comparison and with a few exceptions, linear associations across all measures of turbidity under field and laboratory conditions typically were strong (figs. 8A, 11A; tables 5-11). However, linear associations were not necessarily 1:1 and varied by type of standard, type of sensor, and test condition (field or laboratory). The most consistent association was between the YSI EXO and YSI 6136 turbidity sensorsYSI EXO-measured turbidity values were either similar to or less than YSI 6136-measured turbidity values.

The mean RPDs between all but a few comparisons were greater than 10 percent but less than 30 percent (figs. $8 B, 11 B$; tables 5-11). In addition, mean or median values were statistically different in most comparisons. These differences indicate that turbidity values differ when the same type of sensor is calibrated in different standards or when two different types of sensor are used. However, differences were inconsistent across the laboratory and field conditions, precluding the ability to formulate definitive statements of consistent directional bias depending on the type of standard or sensor used.

There did appear to be some variability between measurements made with polymer-calibrated sensors (comparing different lot numbers from the same manufacturer in the same medium) (figs. 10A, $B$; table 9). One of the polymer lot numbers did not read in a consistent manner with the others in the Hach 2100AN turbidimeter, an error that would not have been noticed had there been no independent method of validation. Directional differences were observed in turbidity measurements made with sensors calibrated by using polymers with different lot numbers (figs. 10A, B). These differences could be caused by the variability between lots at the two points commonly used as calibration setpoints altering sensor response slopes. This variability can be reduced by independently verifying the standard in a calibrated instrument; in this study, the Hach 2100AN was used to verify each standard.

Differences between the YSI EXO and YSI 6136 turbidity sensors were consistently greater than those stated in Yellow Springs Instruments (2012a) - "up to 10 percent"under all conditions tested. However, this discrepancy is not necessarily indicative of poor sensor design but, rather, is consistent with reasonable expectations when using any two different turbidity sensors (Lewis and others, 2007). A consistent bias between the two sensor types was not observed, but either associations were near 1:1 or turbidity measurements for the YSI EXO were lower than those for the YSI 6136. Even though RPDs typically exceeded the 10- and 30-percent thresholds, absolute differences in YSI EXO and YSI 6136 turbidity measurements were small. For example, in the field comparisons, about 94 percent of differences for all comparisons were less than 20 FNU. At lower turbidities (less than $100 \mathrm{FNU}), 95$ percent of differences for all comparisons were less than 10 FNU (fig. 11C).
Particles in suspension in flowing waters create inherent variability in turbidity. This variability causes instability in turbidity readings across the range of conditions tested in the laboratory. Variability in turbidity readings also affects observed differences between two sensors. For example, in laboratory experiments, when turbidity was "constant," the difference between YSI 6136- and YSI EXO-measured turbidity values ranged from near 0 FNU to nearly $400 \mathrm{FNU}$ (figs. 12-13). Under field conditions, inconsistencies in local hydrology and sediment characteristics (such as sediment color) can also cause variability in measurements of turbidity. This variability makes comparison between standards and sensor types challenging.

Given the inherent variability in turbidity measurements and the lack of consistent bias between calibration standards or sensors, changing methods during an ongoing study would compromise the comparability of the data. The effect of changing methods ultimately depends on study objectives. If method changes are required, laboratory- and field-based comparisons across a range of conditions ideally would be conducted to determine whether site-specific biases can be identified. However, correcting measurements from one type of calibration standard or sensor to those from another can introduce an unquantifiable error. In this study, although RPDs commonly exceeded the 10-percent threshold, absolute differences in most turbidity measurements were relatively small. Data objectives should be carefully considered before data corrections based on calibration-standard or sensor comparison data are applied.

\section{Summary}

The challenges associated with field turbidity measurements are well known and result primarily from reported values that depend on instrument design and the resulting need for reporting units that are specific to those designs. A critical challenge for ensuring the comparability of turbidity measurements is the selection and use of appropriate turbidity standards for sensor calibration. The accepted primary standard for turbidity measurements is that made from scratch formazin; all others should relate back to readings obtained by using formazin. However, because turbidity is a relative measurement of light scattering in water, comparing standards is not as simple a process as it is for many chemical measurements. The U.S. Geological Survey (USGS) "National Field Manual for the Collection of Water-Quality Data" currently allows for the use of two standards, formazin and polymer beads, for the calibration of field turbidimeters.

Another challenge for making comparable turbidity measurements is selection of turbidity sensors. A turbidity sensor commonly used by the USGS, the Yellow Springs Instruments (YSI) 6136, has been replaced by the manufacturer with the YSI EXO turbidity sensor. Both sensors operate on the same principles but have slight design differences that result in 
readings that are not comparable on a 1:1 basis. The objectives of this study were to evaluate the response of these two YSI turbidity sensors in StablCal and polymer turbidity standards and to compare the YSI EXO and YSI 6136 turbidity sensors under similar laboratory and environmental (field) conditions. To quantify these differences, a series of laboratory and field side-by-side comparisons were conducted. Nine field comparisons of the YSI EXO and YSI 6136 sensors were performed at site locations in Kansas and Virginia. Two field comparisons of StablCal and polymer calibration standards were performed in Kansas, both using YSI EXO turbidity standards. Five laboratory comparisons between the YSI EXO and YSI 6136 turbidity sensors were performed, and seven laboratory comparisons between StablCal and polymer turbidity standards were performed using YSI EXO turbidity sensors.

Regardless of the comparison, strong linear associations typically were observed across all measures of turbidity under field and laboratory conditions. However, linear associations were not necessarily 1:1 and varied by type of standard, type of sensor, and field and laboratory conditions. The most consistent association was between measurements made with the YSI EXO and YSI 6136 turbidity sensors, where the YSI EXO-measured turbidity values were either similar to or smaller than YSI 6136-measured turbidity values.

Mean relative percentage differences (RPDs) for all but a few comparisons were greater than 10 percent but less than 30 percent. In addition, mean or median values were statistically different in most comparisons. These differences indicate that turbidity values are different when the same type of sensor is calibrated in different standards or when two different types of sensor are used. However, differences were inconsistent across the laboratory and field conditions measured in this study, precluding the ability to formulate definitive statements of consistent directional bias depending on which type of standard or sensor is used.

There did appear to be some variability between polymercalibrated sensors (comparing different lot numbers from the same manufacturer in the same medium). One of the polymer lot numbers was not consistent with the others in the Hach 2100AN benchtop turbidimeter, an error that would not have been caught had there been no independent method of validation. Directional differences were observed in turbidity data collected with sensors calibrated by using different polymer lot numbers. These differences could be caused by the variability between lots at the two points commonly used as calibration setpoints altering sensor response slopes. Different sensors handle calibration slopes - that is, the slope interpolated between setpoints - differently. A discussion of individual sensor calibration slopes is sometimes provided by the manufacturer. This variability can be reduced by independently verifying the standard in a calibrated instrument; in this study, the Hach 2100AN was used to verify each standard.

Differences between the YSI EXO and YSI 6136 turbidity sensors were consistently greater than 10 percent under all conditions tested. However, this discrepancy is not necessarily indicative of poor sensor design but, rather, is consistent with reasonable expectations when using any two different turbidity sensors. A consistent bias between the two sensor types was not observed, but either associations were near 1:1 or turbidity measurements made with the YSI EXO were lower than those made with the YSI 6136. Even though RPDs typically exceeded the 10- and 30-percent thresholds established for this study, absolute differences between measurements made with the YSI EXO and YSI 6136 turbidity sensors were small. For example, in the field comparisons, differences for about 94 percent of all comparisons were less than $20 \mathrm{FNU}$. At lower turbidities (less than $100 \mathrm{FNU}$ ), differences for 95 percent of all comparisons were less than $10 \mathrm{FNU}$.

Particles in suspension in flowing waters create inherent variability in turbidity. This variability causes instability in turbidity readings across the range of conditions tested in the laboratory. Variability in turbidity readings also affects observed differences between two sensors. For example, in laboratory experiments, when turbidity was "constant," the absolute difference between YSI EXO- and YSI 6136-measured turbidity values for field-collected sediment ranged from near 0 up to nearly $400 \mathrm{FNU}$. Under field conditions, local hydrology and sediment characteristics (such as sediment color) are not consistent across time or space and can also cause variability in measurements of turbidity. Substantial variability in turbidity measurements makes comparison between standards and sensor types challenging.

Given the inherent variability in turbidity measurements and the lack of consistent bias between calibration standards or sensors, changing methods during an ongoing study would compromise the comparability of the data. The effect of changing methods ultimately depends on study objectives. If method changes are required, laboratory- and field-based comparisons across a range of conditions ideally would be conducted to determine whether site-specific biases can be identified. However, correcting measurements from one type of calibration standard or sensor to those from another can introduce an unquantifiable error. In this study, although RPDs commonly exceeded the 10-percent threshold, absolute differences in most turbidity measurements were relatively small. Data objectives should be carefully considered before data corrections based on calibration-standard or sensor comparison data are applied. 


\section{References Cited}

AMCOClear, 2020, Turbidity calibration standards evaluated from a different perspective: GFS Chemicals, Inc., web page, accessed June 25, 2020, at amcoclear.com/articles/ turbidity.perspective.php.

Anderson, C.W., 2005, Turbidity (ver. 2.1, September 2005): U.S. Geological Survey Techniques of Water-Resources Investigations, book 9, chap. A6.7, 55 p., accessed July 2, 2020, at https://pubs.er.usgs.gov/publication/twri09A6.7.

Chesterman, C.W., 1978, The Audubon Society field guide to North American rocks and minerals: New York, Alfred A. Knopf, Inc., 849 p.

Hach, 2013, 2100 Series laboratory turbidimeters: Hach Company data sheet, 4 p., accessed September 18, 2017, at https://www.hach.com/asset-get.download-en.jsa?id= 7639982021 .

Hach, 2014, 2100AN user's manual (6th ed., November 2014): Loveland, Colo., Hach Company, 62 p., accessed September 15, 2017, at https://www.hach.com/ asset-get.download.jsa?id=10612025352.

Helsel, D.R., and Hirsch, R.M., 2002, Statistical methods in water resources-Hydrologic analysis and interpretation: U.S. Geological Survey Techniques of Water-Resources Investigations, book 4, chap. A3, 510 p.

International Organization for Standardization, 1999, Water quality_-Determination of turbidity: Geneva, Switzerland, International Organization for Standardization, ISO 7027, 10 p..

King, L.R., 2021, Laboratory and field data for selected turbidity standard and sensor comparisons, October 2014 to September 2017: U.S. Geological Survey data release, https://doi.org/10.5066/P9EVSDHH.

Lewis, J., Eads, R., and Klein, R.D., 2007, Comparisons of turbidity data collected with different instruments: Santa Rosa, Calif., report to the California Department of Forestry and Fire Protection and the North Coast Regional Water Quality Control Board, 19 p.

R Core Team, 2015, R-A language and environment for statistical computing: Vienna, Austria, R Foundation for Statistical Computing software release. [Also available at https://www.r-project.org/.]

Rasmussen, P.P., Gray, J.R., Glysson, G.D., and Ziegler, A.C., 2009, Guidelines and procedures for computing time-series suspended-sediment concentrations and loads from in-stream turbidity-sensor and streamflow data: U.S. Geological Survey Techniques and Methods, book 3, chap. C4, 52 p.
Sadar, M., 2003, Turbidity sStandards: Hach Company Technical Information Series, booklet 12, ed. 1, 18 p., accessed September 15, 2017, at https:/www.hach.com/ asset-get.download.jsa?id=7639984480.

Sokal, R.R., and Rohlf, F.J., 1995, Biometry-The principles and practice of statistics in biological research ( $3 \mathrm{~d}$ ed.): New York, W.H. Freeman and Company, 887 p.

Systat Software, Inc., 2008, SigmaPlot 11.0 statistics user's guide: Systat Software, Inc., 564 p.

U.S. Environmental Protection Agency, 1993, Method 180.1-Determination of turbidity by nephelometry (rev. 2.0, August 1993): U.S. Environmental Protection Agency Method 180.1, $10 \mathrm{p}$.

Van Valkenburg, S., Lawrence, J., and Stetson, S., 2016, Turbidity, nephelometric: National Water Quality Laboratory (NWQL) Standard Operating Procedure (SOP) INCW0173.6, June 2016.

Wagner, R.J., Boulger, R.W., Jr., Oblinger, C.J., and Smith, B.A., 2006, Guidelines and standard procedures for continuous water-quality monitors-Station operation, record computation, and data reporting: U.S. Geological Survey Techniques and Methods, book 1, chap. D3, 51 p.

Yellow Springs Instruments (YSI), 2012a, EXO water quality field sensors-Features, specifications, and comparability to YSI 6-series sensors (rev. B): Yellow Springs, Ohio, Yellow Springs Instruments, $14 \mathrm{p}$.

Yellow Springs Instruments (YSI), 2012b, 6-Series multiparameter water quality sondes-User manual: Yellow Springs, Ohio, Yellow Springs Instruments, revision J, 379 p., accessed September 15, 2017, at https://www.ysi.com/File\%20Library/Documents/Manuals/ 069300-YSI-6-Series-Manual-RevJ.pdf.

Yellow Springs Instruments (YSI), 2016, Turbidity units and calibration solutions: Yellow Springs Instruments Turbidity Sensors Technical Note T627, 2 p., accessed June 15, 2018, at https:/www.ysi.com/File\%20Library/ Documents/Technical\%20Notes/T627_Turbidity_Units_ and_Calibration_Solutions.pdf.

Yellow Springs Instruments (YSI), 2017, EXO user manual-Advanced water quality monitoring platform: Yellow Springs, Ohio, Yellow Springs Instruments, revision G, 154 p., accessed September 15, 2017, at https://www.ysi.com/File\%20Library/Documents/Manuals/ EXO-User-Manual-Web.pdf.

Zar, J.H., 1999, Biostatistical analysis 4th ed.: New Jersey, Prentice-Hall Inc., 663 p. 


\section{Appendixes 1-23}

[All appendixes are available for download at https://doi.org/10.3133/ofr20211009] 
Appendix 1. Field Comparison Between StabICal and Polymer Turbidity Standards at Neosho River at Burlingame Road Near Emporia, Kansas (U.S. Geological Survey Station Number 07179750), May 16 to June 27, 2017

Appendix 2. Field Comparison Between StabICal and Polymer Turbidity Standards at Kansas River at De Soto, Kansas (U.S. Geological Survey Station Number 06892350), May 16 to June 24, 2017

Appendix 3. Laboratory Comparison Between StabICal and Polymer Turbidity Standards Using White Clay at the Kansas Water Science Center Laboratory, Lawrence, Kansas

Appendix 4. Laboratory Comparison Between StabICal and Polymer Turbidity Standards Using Pink Clay at the Kansas Water Science Center Laboratory, Lawrence, Kansas

Appendix 5. Laboratory Comparison Between StabICal and Polymer Turbidity Standards Using Natural Sediment and Water (From the Neosho River at Neosho Rapids, Kansas, U.S. Geological Survey [USGS] Station Number 07182390) at the Kansas Water Science Center Laboratory, Lawrence, Kansas

Appendix 6. Laboratory Comparison Between StabICal and Multiple Lots of Polymer Turbidity Standard at the Kansas Water Science Center Laboratory, Lawrence, Kansas

Appendix 7. Laboratory Comparison Between StabICal and Multiple Lots of Polymer Turbidity Standard Using Natural Sediment and Water (From the Neosho River at Neosho Rapids, Kansas, U.S. Geological Survey [USGS] Station Number 07182390) at the Kansas Water Science Center Laboratory, Lawrence, Kansas on September 7, 2017

Appendix 8. Laboratory Comparison Between StabICal and Multiple Lots of Polymer Turbidity Standard Using White Clay at the Kansas Water Science Center Laboratory, Lawrence, Kansas 
Appendix 9. Laboratory Comparison Between StabICal and Multiple Lots of Polymer Turbidity Standard Using Natural Sediment and Water (From the Neosho River at Neosho Rapids, Kansas, U.S. Geological Survey Station Number 07182390) at the Kansas Water Science Center Laboratory, Lawrence, Kansas on September 15, 2017

Appendix 10. Field Comparison Between YSI EXO and YSI 6136 Turbidity Sensors at Little Arkansas River at Highway 50 Near Halstead, Kansas (U.S. Geological Survey [USGS] Station Number 07143672), January 25 to June 28, 2017

Appendix 11. Field Comparison Between YSI EXO and YSI 6136 Turbidity Sensors at Little Arkansas River Near Sedgwick, Kansas (U.S. Geological Survey [USGS] Station Number 07144100), March 30 to June 28, 2017

Appendix 12. Field Comparison Between YSI EXO and YSI 6136 Turbidity Sensors at North Fork Ninnescah River Above Cheney Reservoir, Kansas (U.S. Geological Survey [USGS] Station Number 07144780), March 31 to June 7, 2017

Appendix 13. Field Comparison Between YSI EXO and YSI 6136 Turbidity Sensors at Cheney Reservoir Near Cheney, Kansas (U.S. Geological Survey [USGS] Station Number 07144790), October 1, 2014 to March 12, 2015

Appendix 14. Field Comparison Between YSI EXO and YSI 6136 Turbidity Sensors at Neosho River at Neosho Rapids, Kansas (U.S. Geological Survey [USGS] Station Number 07182390), April 4 to May 9, 2017

Appendix 15. Field Comparison Between YSI EXO and YSI 6136 Turbidity Sensors at Neosho River at Burlington, Kansas (U.S. Geological Survey [USGS] Station Number 07182510), May 9 to May 16, 2017

Appendix 16. Field Comparison Between YSI EXO and YSI 6136 Turbidity Sensors at Mill Creek at Johnson Drive, Shawnee, Kansas (U.S. Geological Survey [USGS] Station Number 06892513), August 16 to August 31, 2017

Appendix 17. Field Comparison Between YSI EXO and YSI 6136 Turbidity Sensors at James River at Cartersville, Virginia (U.S. Geological Survey [USGS] Station Number 02035000), October 7, 2016 to July 10, 2017 
Appendix 18. Field Comparison Between YSI EXO and YSI 6136 Turbidity Sensors at Difficult Run Above Fox Lake Near Fairfax, Virginia (U.S. Geological Survey [USGS] Station Number 01645704), May 6 to July 25, 2017

Appendix 19. Laboratory Comparison Between YSI EXO and YSI 6136 Turbidity Sensors Using White Clay at the Kansas Water Science Center Laboratory, Lawrence, Kansas

Appendix 20. Laboratory Comparison Between YSI EX0 and YSI 6136 Turbidity Sensors Using Black Clay at the Kansas Water Science Center Lab, Lawrence, Kansas

Appendix 21. Laboratory Comparison Between YSI EXO and YSI 6136 Turbidity Sensors Using Pink Clay at the Kansas Water Science Center Laboratory, Lawrence, Kansas

Appendix 22. Laboratory Comparison Between YSI EXO and YSI 6136 Turbidity Sensors Using Natural Sediment and Water (From Mill Creek at Johnson Drive, Shawnee, Kansas, U.S. Geological Survey [USGS] station number 06892513) at the Kansas Water Science Center Lab, Lawrence, Kansas

Appendix 23. Laboratory Comparison Between YSI EXO and YSI 6136 Turbidity Sensors Using Natural Sediment and Water (From the Kansas River at Wamego, Kansas, U.S. Geological Survey [USGS] Station Number 06887500) at the Kansas Water Science Center Lab, Lawrence, Kansas 

For more information about this report, contact:

Director, New York Water Science Center

U.S. Geological Survey

425 Jordan Road

Troy, NY 12180-8349

dc_ny@usgs.gov

(518) 285-5602

or visit our website at https://www.usgs.gov/centers/ny-water

Publishing support provided by the

Pembroke and West Trenton Publishing Service Centers 
